IZA DP No. 8764

Voluntary Activities and Daily Happiness in the US

J. Ignacio Gimenez-Nadal Jose Alberto Molina

January 2015 


\title{
Voluntary Activities and Daily Happiness in the US
}

\author{
J. Ignacio Gimenez-Nadal \\ University of Zaragoza \\ and CTUR
}

\section{Jose Alberto Molina}

University of Zaragoza

and IZA

\section{Discussion Paper No. 8764 \\ January 2015}

\author{
IZA \\ P.O. Box 7240 \\ 53072 Bonn \\ Germany \\ Phone: +49-228-3894-0 \\ Fax: +49-228-3894-180 \\ E-mail: iza@iza.org
}

Any opinions expressed here are those of the author(s) and not those of IZA. Research published in this series may include views on policy, but the institute itself takes no institutional policy positions. The IZA research network is committed to the IZA Guiding Principles of Research Integrity.

The Institute for the Study of Labor (IZA) in Bonn is a local and virtual international research center and a place of communication between science, politics and business. IZA is an independent nonprofit organization supported by Deutsche Post Foundation. The center is associated with the University of Bonn and offers a stimulating research environment through its international network, workshops and conferences, data service, project support, research visits and doctoral program. IZA engages in (i) original and internationally competitive research in all fields of labor economics, (ii) development of policy concepts, and (iii) dissemination of research results and concepts to the interested public.

IZA Discussion Papers often represent preliminary work and are circulated to encourage discussion. Citation of such a paper should account for its provisional character. A revised version may be available directly from the author. 


\section{ABSTRACT}

\section{Voluntary Activities and Daily Happiness in the US ${ }^{*}$}

This paper analyzes differences in daily happiness between those individuals in the United States who perform voluntary activities during the day, and those who do not. Using the WellBeing Module of the American Time Use Survey 2010, we initially find that those who devote any time to voluntary activities during the day report higher levels of daily happiness than those who do not. Comparing the happiness obtained from a range of activities, we find that volunteering is among the most enjoyable, indicating that time spent on voluntary activities is utility-enhancing. But when the issue of reverse causality is taken into account, we find no differences in daily happiness between volunteers and non-volunteers, which indicates that happier individuals are also more likely to volunteer. We document that the effect of voluntary activities on the experienced utility of individuals can be decomposed into a "timecomposition" effect and a "personality" effect, with the latter explaining between $11 \%$ and $46 \%$ of the observed difference.

JEL Classification: D13, J16, J22

Keywords: voluntary activities, time use survey, experienced utility

Corresponding author:

Jose Alberto Molina

Department of Economic Analysis

Faculty of Economics

University of Zaragoza

Gran Vía 2

50005 Zaragoza

Spain

E-mail: jamolina@unizar.es

\footnotetext{
* We are very grateful for helpful comments from Jon Bakija, Bram de Brock, Andrew Clark, Donald Cox, Dan Hamermesh, Andreas Knäbe, Eric Maurin, Alois Stutzer, Yu Zhu, and participants in the Workshop "Frontiers of Time Use Research" (Paris, 2014). This paper was partially written while Jose Alberto Molina was Visiting Fellow at the Department of Economics of Boston College (US), to which he would like to express his thanks for the hospitality and facilities provided. This paper has benefited from funding from the Spanish Ministry of Economics (Project ECO2012-34828).
} 


\section{Introduction}

We analyze here the relationship between voluntary activities and the happiness obtained throughout the day by individuals in the US, which has a long tradition of community service and continues to lead other Western countries in volunteering. American adults are more than twice as likely as German and French adults to contribute time and energy to community work (Ladd, 1999; Putnam, 2000), and participation in voluntary activities has increased in recent years (US BLS 2013a). Voluntary activity is a significant economic activity in the US. Americans aged 15 and older spent 2.5 hours, on average, doing formal and informal volunteering on days that they volunteered, with between $6 \%$ and $8 \%$ of the US population volunteering on any given day, over the period 2007-2011 (US BLS 2013b). Volunteering plays a prominent role in the charitable provision of goods and services, and it is often regarded as being fundamental to the sustainability of any society. Hence, the factors and/or motives behind individual philanthropic behavior are worth analyzing, as a deeper understanding of charitable donations of time could help economists and policy-makers anticipate behavioral responses to changes in economic fundamentals.

Among the different hypotheses as to why individuals devote time to voluntary activities, one basic idea is that it increases the utility of individuals (Becker, 1974; Andreoni, 1989;1990). The literature on the determinants of happiness (or Subjective Well-Being, SWB) has studied the factors that make individuals happier, with some studies showing that volunteering is positively related to individual SWB (Dolan, Peasgood and White, 2008; Meier and Stutzer, 2008; Binder and Freytag, 2013). ${ }^{1}$ But many of the studies are correlational, and the causal relationship between volunteering and happiness must be approached with caution. In this paper, we take an alternative approach, and we examine the happiness obtained by individuals during their daily activities. ${ }^{2}$ Within this framework, we compare the daily happiness obtained by individuals who do, or do not, devote time to voluntary activities. To that end, we use the sample of individuals from the Well-Being Module of the 2010 American Time Use Survey (ATUS), which provides information on individual time use, based on diary questionnaires, in which individuals report their activities throughout the 24 hours of the day, as well as information on the feelings individuals experience during their time-use activities.

We use two measures of daily happiness that have been proposed in the literature, and regress them on an indicator of whether the diarist reported some time spent on voluntary activities during the day of the interview. We find that those who devote any time to voluntary activities during the day report obtaining a higher level of happiness than those who do not

\footnotetext{
${ }^{1}$ See Dolan, Peasgood and White (2008) and Binder and Freytag (2013) for a review of the factors correlated with volunteering and SWB.

${ }^{2}$ This concept refers to the "experienced utility", as used by Kahneman et al. (1997), who defines it as a 'continuous hedonic flow of pleasure or pain'.
} 
devote such time. These results are maintained when we exclude episodes of voluntary activity from the analysis. We further propose an Instrumental Variable strategy to deal with reverse causality e.g., happier individuals could be more likely to participate in voluntary activities. Using the cross-state variations in laws regarding deductions for charitable contributions as our main instrument, we find that voluntary activities have no effect on the daily happiness of volunteers, indicating that happier individuals are more likely to participate in voluntary activities.

We also follow Knabe et al. (2010) and decompose the difference in the daily happiness between volunteers and non-volunteers into two components: a "time-composition" effect and a "personality" effect. The former captures the difference in daily happiness that can be attributed to differences in the distribution of activities during the day. To the extent that different activities provide different levels of individual experienced utility, the difference in the experienced utility between volunteers and non-volunteers could be explained because those who devote time to volunteer activities may differ in how they spend their time, compared to those who do not volunteer. Such differences in the distribution of activity time include voluntary activities that are shown to be ranked among the five most enjoyable activities, consistent with prior studies. For instance, Krueger (2007) analyzes data on experienced utility in the US and classifies the "general voluntary acts" in the group of "the most enjoyable and interesting activities”. Kahneman et al. (2004), Krueger et al. (2009) and White and Dolan (2009) also show that voluntary activities are positively related to happiness.

The latter study captures the variations in daily happiness obtained while engaged in similar activities. It could be that volunteers and non-volunteers report different levels of daily happiness when engaged in the same activities during the day, which could explain the observed differences between the two groups. Such differences are defined at the individual level, as they depend on inter-personal differences in same activities, and we call this the "personality" effect. The "personality" effect explains between $11 \%$ and $46 \%$ of the differences in happiness between volunteers and non-volunteers during the day.

We contribute to the literature by examining the relationship between voluntary activities and the happiness of individuals (Thoits and Hewitt, 2001; Greenfield and Marks, 2004; Brooks, 2006; Borgonovi, 2008; Dolan, Peasgood and White, 2008; Meier and Stutzer, 2008; Binder and Freytag, 2013), by offering a novel analysis of how voluntary activities affect the daily happiness individuals obtain during the day. We initially find that those who volunteer report higher levels of daily happiness, but this difference dissapears when the reverse causality issue is taken into account. This work complements prior analyses on how voluntary labor relates to subjective well-being, but, while other studies have used retrospective questions on happiness or well-being, aimed at measuring happiness in the long-run, our approach focuses on 
the short-run. Thus, whereas traditional SWB measures refer to "life as you remember it", we concentrate here on "life as you live it". Our second contribution is the use of cross-state variations in deductions for charitable contributions as an instrument to deal with the possible reverse causality of volunteering and happiness, given that the majority of existing studies are correlational, with only a few exceptions dealing with the issue of reverse causality. Our third contribution lies in the decomposition of the difference in daily happiness between the two groups into two components with, to the best of our knowledge, only Knabe et al. (2010) having done anything similar.

The rest of the paper is organized as follows. Section 2 presents a review of the most relevant literature for the current study. Section 3 describes the data and variables. Section 4 analyzes initially the relationship between voluntary activities and happiness, and Section 5 examines possible channels through which happiness and volunteering could be related. Section 6 shows the relevant results when the issue of reverse causality is taken into account, and Section 7 shows the decomposition of the difference in daily happiness between the "timecomposition" and "personality” effects. Section 8 sets out our main conclusions.

\section{Literature Review}

Volunteering can be broadly defined as "any activity in which time is given freely to benefit another person, group or organization” (Wilson, 2000, pp. 215). In Economics, explanations of the philantrophic behavior of individuals vary. One of these is the straightforward utilitymaximization model, where donors obtain tangible benefits, in line with the basic notion of a rational "homo-economicus". If we relax the utility-maximization assumption, giving may take place when individuals are interested in the well-being of others, leading to the "pure altruism model” (e.g., Becker, 1974; Unger, 1991; Duncan, 1999), or it may take place when donors derive benefit from the act of giving, leading to the "impure altruism" or "warm glow" model (Andreoni, 1989;1990; Rose-Ackerman, 1996). The "investment model" considers that volunteering may enable individuals to accumulate human capital, expand networks, signal productive characteristics to firms, or acquire contacts that can help in the future (e.g., Menchik and Weisbrod, 1987; Freeman, 1997, Wilson, 2012). Hence, the consumption motive is associated with the first three explanations, as there are direct increases of the contemporaneous utility of individuals from volunteering, and the investment motive considers an indirect increase in future utility. Menchik and Weisbrod (1987) analyze each of these motives and conclude that both play an important role in the decision to volunteer, although Freeman (1997) fails to confirm the importance of the consumption motive. 
Several positive outcomes have been proposed as being associated with volunteering, including increased health (Post, 2005) and well-being (see Dolan, Peasgood and White, 2008, for a review). Volunteering has also been seen as positively related to the subjective well-being of volunteers (Helliwell, 2003; Helliwell and Putnam, 2004; Post, 2005; Brooks, 2006; Pichler, 2006; Becchetti et al., 2008; Borgonovi, 2008; Dolan, Peasgood and White, 2008). However, very few of these studies take into account issues of reverse causality (people volunteer more when they are happy) and simultaneity biases (some third factor, such as religion, leads to more volunteering and to more happiness). Meier and Stutzer (2008) find that the impact of volunteering is considerably reduced when fixed effects are controlled for, and only volunteering weekly remains significant, suggesting that the higher levels of well-being arise from individual heterogeneity. Binder and Freytag (2013) apply matching estimators and find that the impact of regular volunteering on SWB is positive and increasing over time when regular volunteering is sustained. Others have found that volunteering is negatively related to subjective well-being (Li, Pickles and Savage, 2005; Bjørnskov, 2003).

Demographic characteristics have been found to be among the factors affecting volunteering. Prior literature has found that education is a significant factor in the decision to volunteer (Huang, van den Brick and Groot, 2009; Wilson, 2012). Other variables are being male (Wilson and Musick, 1999), being white (Rotolo, Wilson and Hughes, 2010), and being middle-aged (Wilson, 2012). Income, apparently, has no effect on the volunteer behavior of individuals (Brooks, 2007), while the unemployed are less likely to volunteer (Wilson, 2000).

Other factors that affect volunteering, and that are more difficult to isolate, are personality traits and the social context. ${ }^{3}$ Regarding personality traits, among the "Big Five" personality dimensions - extraversion, agreeableness, conscientiousness, neuroticism, and openness (Gosling et al., 2003) - some studies have found a positive relationship between extraversion and agreeableness, and the likelihood of volunteering (Bekkers, 2010; Omoto et al., 2010). These findings indicate the importance of the unobserved heterogeneity of individuals in determining volunteer behavior. Alternatively, prestige and reputation have been proposed as influential factors (Glazer and Konrad, 1996; Ostrower, 1997; Bénabou and Tirole, 2005; Meier and Stutzer, 2010; Ariely, Bracha and Meier, 2009; Shang and Crosson, 2009, Bekkers, 2010; Carpenter and Myers, 2010). The social context has been shown to be an important factor in voluntary behavior, as larger social networks seem to increase the propensity to volunteer (Okun et al., 2007), while trust in other people also can be positively related to volunteering (Brehm and Rahn, 1997; Putnam, 2000). Additionally, religion seems to be positively related to volunteering, at least in the US (Brooks, 2006; Borgonovi, 2008).

\footnotetext{
${ }^{3}$ See Binder and Freytag (2013) for a review of the literature on the relationship between volunteering, personality traits, and social context.
} 
Finally, and regarding the factors associated with the experienced utility of individuals, Kahneman et al. (2004), using data on experienced utility for a sample of 909 working women in the US, found that activities done in the presence of friends, relatives, and the spouse and children are superior in terms of utility, compared to acting alone, which shows the importance of taking into account the presence of others while individuals are doing their daily activities. Sevilla, Gimenez-Nadal and Gershuny (2012) find that, for both the United Kingdom and the United States, the presence of young children is associated with greater hapiness. Furthermore, Krueger (2007) classifies "general voluntary acts" in the group of "the most enjoyable and interesting activities”, finding that characteristics such as age, being male, and having a higher educational level are all factors related to lower experienced utility. Thus, it is important to control for the socio-demographic characteristics of the individuals in our regressions, in order to net out the effects of volunteering from the effects of such factors, as different individuals may have different volunteering behavior. Also, the presence of others during the activity of reference must also be taken into account, to net out the effect of volunteering from the effect of other factors.

\section{Data, sample and variables}

We use the Well-being Module from the 2010 American Time Use Survey to establish a link between daily happiness and voluntary activities. The module for time use information was added to the ATUS diary to capture how individuals felt during selected activities, and was fielded from January through December, 2010. Respondents were first asked to fill out a diary summarizing episodes of the preceding day. The advantage of time-use surveys over stylizedquestions, such as those included in the European Community Household Panel (ECHP), the British Household Panel Survey (BHPS), and the German Socio-Economic Panel (GSOEP), where respondents are asked how much time they have spent, for example, in the previous week, or normally spend each week, on market work or housework, is that diary-based estimates of time use are more reliable and accurate than estimates derived from direct questions (Juster and Stafford, 1985; Robinson and Godbey, 1985; Bianchi et al., 2000; Bonke, 2005; Yee-Kan, 2008).

There are several methodologies to assess the link between activities and feelings. The process benefits approach uses Activity Enjoyment Ratings, where respondents are asked to rate on a scale from 0 to 10 how much they enjoyed a certain type of activity (Juster and Stafford, 1985). The experienced utility approach proposes the Experience Sampling Method as a superior way to collect objective instantaneous enjoyment data, and where information on hedonic experiences (or instant enjoyment) in real time is collected. Alternative methods of collecting data on hedonic experience, such as the conventional yesterday diary used in time-budget 
surveys (Szalai, 1972) or the Day Reconstruction Method (Kahneman et al., 2004), are less costly to implement. Both methods collect information on how the respondent experienced all or some of the activities he or she engaged in during the previous day, as described in a time-use diary. Specifically, the Well-Being Module of the ATUS (2010) uses the Day Reconstruction Method, where three episodes from the preceeding day, lasting at least five minutes, are randomly selected and diarists are asked to rank on a 7-point scale the extent to which they were happy, stressed, sad, tired, or felt pain during the activity, with " 0 " indicating "did not experience the feeling at all" and "6" indicating "feeling was extremely strong". The type of well-being that can be measured with the ATUS Well-Being Module refers to the objective happiness experienced by individuals throughout the day.

\section{Sample and variables}

For the sake of comparison with prior studies (Aguiar and Hurst, 2007; Gimenez-Nadal and Sevilla, 2012), and to minimize the role of time-allocation decisions, such as education and retirement, that have a strong inter-temporal component over the life cycle, we restrict the sample used throughout our analysis to non-retired/non-student individuals between the ages of 21 and 65 (inclusive). ${ }^{4}$ From the original sample of 37,935, the selection of individuals for our study gives us 26,099 observations, obtaining a final sample 25,601 episodes, from 8,746 individuals, when we eliminate observations with missing socio-demographic information.

We use two dependent variables throughout the paper. The first refers to the net-affect, defined as the difference between the average score the respondent gives to all positive attributes, and the average score of all negative attributes. In our case, for one episode, it can be defined as the average score the respondent gives to all positive attributes (happiness), minus the average score of all negative attributes (stress, tiredness, sadness, or pain). We define $A_{i j}$ as the individual “i” net-affect during activity " $\mathrm{j}$ ”, as follows:

$$
A_{i j}=\frac{\sum_{l=1}^{L} P A_{i j}^{l}}{L}-\frac{\sum_{k=1}^{K} N A_{i j}^{K}}{K}
$$

where $P A_{i j}^{l}$ represents the affect score of the l-th (out of $\mathrm{L}$ ) positive emotion individual "i" reports for activity “j”, and $N A_{i j}^{k}$ represents the affect score of the k-th (out of K) negative

\footnotetext{
${ }^{4}$ We have alternatively analysed individuals between 15 and 85 years old. Results are qualitatively the same, with the only difference being that the variations in daily happiness reported by those who did any voluntary activity during the day, compared to those who did not, are larger compared to our main results. Also, when we restrict the analysis to retired people over age 64, we find that the difference in experienced utility reported by those who did any voluntary activity during the day, compared to those who did not, is larger compared to our main results (results are available upon request). This can be explained by the fact that prior research has found that elderly individuals profit strongly from volunteering work in terms of well-being (Greenfield and Marks, 2004; Choi and Kim, 2011; Dulin et al., 2012) which may be explained by the fact that elderly people who volunteer are less isolated (Musick and Wilson, 2003; Onyx and Warburton, 2003).
} 
emotion. The net-affect is a cardinal measure, based on the assumption that utility is timeseparable, which leads the net-affect to be a meaningful representation of the utility derived from a given experience (Kahneman et al., 2004). This measure can take any value from -6 to 6 . However, one disadvantage of the net-affect is that it is unclear what the scale of measurement really refers to, and whether different individuals interpret the scale in the same way.

The second dependent variable refers to the u-index, also known as the misery index, that measures the proportion of time that is spent in an unpleasant state, and for a given episode is defined as equal to 1 if the maximum rating of any of the negative emotions (stress, tiredness, sadness, pain) strictly exceeds the rating of happiness, and 0 if not. For instance, if for a given episode we have a value of 3 for happiness, and we have a higher value $(4,5$ or 6$)$ for any of the other feelings (stress, tiredness, sadness, pain), the u-index takes value "1". But if, for a given episode, we have a value of 4 for happiness, and we have lower or equal values (1, 2, 3 and 4) for the other feelings, the u-index takes value " 0 ”. We define $\mathrm{U}_{\mathrm{ij}}$ as the individual " $\mathrm{i}$ ” $\mathrm{u}$-index during activity “j” as follows:

$$
\mathrm{U}_{i j}=\left\{\begin{array}{c}
1 \text { if } \max \left(\mathrm{NA}_{\mathrm{ij}}^{1}, \ldots ., \mathrm{NA}_{\mathrm{ij}}^{\mathrm{k}}, \ldots \ldots ., \mathrm{NA}_{\mathrm{ij}}^{\mathrm{K}}\right)>\max \left(\mathrm{PA}_{\mathrm{ij}}^{1}, \ldots . ., \mathrm{PA}_{\mathrm{ij}}^{\mathrm{l}}, \ldots \ldots ., \mathrm{PA}_{\mathrm{ij}}^{\mathrm{L}}\right) \\
0 \text { otherwise }
\end{array}\right.
$$

where $P A_{i j}^{l}$ represents the affect score of the l-th (out of $\mathrm{L}$ ) positive emotion individual "i" reports for activity " $\mathrm{j}$ ”, and $N A_{i j}^{k}$ represents the affect score of the k-th (out of K) negative emotion. This measure is defined between the values " 0 " and " 1 ". The main advantage of the uindex over the net-affect is that the u-index is independent of scale effects and avoids the problem of individual interpretation. One disadvantage of the u-index is that the assessment of feelings is truly ordinal, and it depends on what emotions are included in the questionnaire.

Table 1 shows means and standard deviations of the net-affect and the u-index for individuals in our sample. The overall values for the net-affect and the u-index are 2.768 and 0.261 , respectively. ${ }^{5}$ Considering the u-index, which yields a more direct interpretation, we observe that during $26 \%$ of their time, individuals in the US are in an unpleasant state (i.e. any of the negative feelings overcomes the positive feeling). A comparison of the mean value of the u-index and prior research indicates that the mean value for our sample differs (e.g., Krueger,

\footnotetext{
${ }^{5}$ The overall values are calculated using the duration weights of the episodes included in the Well-Being Module of the ATUS. There was an error in the activity selection process, and due to a programming error in the data collection software, certain activities were less likely than others to be selected for follow-up questions in the module. The last eligible activity in each respondent's time diary was incorrectly excluded from the random selection process in most cases. As a result, eligible activities that occur at or near the end of the diary are underrepresented in the data. For example, the last eligible diary activity often is a long spell of TV watching; because of the selection error, TV watching is underrepresented in the WB Module data and the average duration of activities selected for the module is shorter than the average duration of all eligible diary activities. Consequently, well-being activity weights are adjusted to compensate for those activities that were underrepresented.
} 
2007; Krueger et al, 2009), as the u-index presents a higher value. In particular, the mean value for the u-index in Krueger (2007) and Krueger et al. ( 2009) is around 0.19. The reason for such difference can be explained by sample selection issues. In our sample, we select individuals between 21 and 65 who are not students and not retired, and thus the proportion of individuals who work is likely to be higher, compared to other analyses based on more general samples. To the extent that individuals who are employed devote time to market work and commuting, activities that have been shown to be very unpleasant, this difference can explain why, in our case, individuals obtain lower daily happiness.

If we do the analysis considering whether the diary includes any type of voluntary activity, we observe that there are statistically significant differences between the two groups (i.e. diaries with, and without, voluntary activities). ${ }^{6}$ In the case of the net-affect, we observe that the overall values for diaries with and without voluntary activities are 3.113 and 2.728, respectively, which yields a gap in the net-affect of 0.385 in favour of diaries with voluntary activities. In the case of the u-index, we observe that the overall values for diaries with and without voluntary activities are 0.219 and 0.266 , respectively, which yields a gap in the u-index of -0.047 in favour of diaries with voluntary activities. These differences are statistically significant at standard levels $(\mathrm{p}<0.01)$. From this analysis, we can conclude that there is a raw difference in daily happiness favoring individuals with voluntary activities in their diaries.

In order to better understand the greater daily happiness of volunteers vis-à-vis nonvolunteers, we explore how pleasant single activities are perceived. Table 2 shows a list of 26 activities ranked by the average value of the net-affect (see Appendix A1 for categorization of these activities). The activities at the top are the most enjoyable, while the activities at the bottom can be considered the least enjoyable. Together with non-basic childcare, religious activities, and out-of-home leisure, voluntary activities are in the group of activities that are most enjoyable, with average net-affect and u-index of 3.483 and 0.194 , respectively, with this being consistent with prior results (Kahneman et al., 2004; Krueger, 2007;2009; White and Dolan, 2009; Robinson, 2014). Thus, part of the variation in daily happiness between volunteers and non-volunteers can be explained because voluntary activities are among the most enjoyable,

\footnotetext{
6 We consider voluntary activities to include the following ATUS categories: "Computer use (volunteer)", "Organizing and preparing (volunteer)", "Reading (volunteer)", “Telephone calls (volunteer, except hotline counseling)", "Writing (volunteer)", "Fundraising (volunteer)", "Administrative and support activities (volunteer)", "Food preparation, presentation, and clean-up (volunteer)", "Collecting and delivering clothing and other goods (volunteer)", "Providing care (volunteer)", "Teaching, leading, counseling, mentoring (volunteer)", "Social service and care activities (volunteer)", "Building houses, wildlife sites, and other structures (volunteer)", "Indoor and outdoor maintenance, repair, and clean-up (volunteer)", "Performing (volunteer)", "Serving at volunteer events and cultural activities (volunteer)", "Participating in performance and cultural activities (volunteer)", "Attending meetings, conferences, and training (volunteer)", "Public health activities (volunteer)", "Public safety activities (volunteer)", "Public health and safety activities (volunteer)", "Waiting associated with volunteer activities", "Security procedures related to volunteer activities", "Civic obligations and participation", and "Waiting associated with civic obligations and participation”.
} 
which increases the daily happiness of individuals. We address in Section 5 the extent to which this difference in voluntary time can explain the difference in daily happiness.

However, the differences in daily happiness are raw differences, not taking into account that socio-demographic differences may partially or totally drive the difference in daily happiness between volunteers and non-volunteers. In order to net out the effect of voluntary activities from the effect of other socio-demographic characteristics, we use several explanatory variables aimed at capturing differences in household and personal characteristics across respondents. We include gender (male), age and its square, dummy variables for university and secondary education, dummies for working full- and part-time, a dummy to control for the presence of children under 18 in the household, a dummy to indicate whether the respondent is married/cohabiting, household income, and dummy variables for region of residence (ref.: West). ${ }^{7}$ Secondary education is defined as having high school level, while university education is defined as having some college, a college degree, or more. Household income refers to the combined income of all family members during the last year and includes wages, net income from business, farm or rent, pensions, dividends, interest, Social Security payments, and any other money income received by family members who are 15 years of age or older. Household income is coded with income brackets with the following values: 1 "Less than \$5,000", 2 “\$5,000 to $\$ 7,499 ”, 3$ “\$7,500 to $\$ 9,999 ”, 4$ “\$10,000 to $\$ 12,499 ”, 5$ “\$12,500 to $\$ 14,999$ ”, 6 “\$15,000 to $\$ 19,999 ”, 7$ “ $\$ 20,000$ to $\$ 24,999 ”, 8$ “\$25,000 to $\$ 29,999 ”, 9$ “\$30,000 to \$34,999”, 10 “\$35,000 to \$39,999”, 11 “\$40,000 to \$49,999”, 12 “\$50,000 to \$59,999”, 13 “\$60,000 to $\$ 74,999 ”, 14$ “\$75,000 to $\$ 99,999 ”, 15$ “\$100,000 to $\$ 149,999 ”$ and 16 “\$150,000 and over”. We consider the mid-point of each interval, and $\$ 150,000$ for the last interval, and we apply the log of the value of each interval to allow for non-linearities in the effect of income.

Furthermore, we include information on whether the activity of reference was done in the presence of others, with being alone as our category of reference. The reason is that the existing literature shows that activities done in the presence of others provide greater daily happiness compared to actitivities done alone. Also, volunteering often involves spending time with others, which is emotionally beneficial. Thus, we include dummy variables to control for whether the activity was done in the presence of household children, the spouse/partner, any other household adult, other close friends, or co-workers. Alternatively, we control for the time spent during the day with others at the diary level.

We also include day-of-week dummies (ref.: Friday) to control for the fact that the time restriction may become more binding during the week, as people who work normally must accomplish their work responsibilities on weekdays, and thus voluntary activities may be more

\footnotetext{
${ }^{7}$ See Appendix Table A2 for summary statistics of the variables in our sample
} 
personally enriching during the week, or more abundant at weekends. Figure 1 shows the distribution of voluntary activities in our sample for the seven days of the week, and it can be seen that around $25 \%$ of voluntary activities are done on Sundays. This is consistent with the previous hypothesis, that time restrictions may become more binding during the week, and people volunteer more during the weekends. This may also be related to religious participation, as many voluntary activities are done on Sundays at church, with this being explored later.

We find that, in comparison with individuals who do not do any voluntary activity during the reference day, those who do present a lower proportion of men, are older, a higher percentage have a university education, a smaller percentage work full-time as opposed to parttime, a higher percentage have at least one child under 18 and live in couple, the household income is higher, and they spend more time with children, the spouse/partner and friends, while spending less time with co-workers. These differences show the importance of controlling for all these characteristics in analyses that follow.

Finally, Kahneman and Krueger (2006) show that the level of tiredness increases during the day. That is, in late hours, individuals report being more tired than in earlier hours. This may affect the differences between individuals if the selection of activities for those who volunteer was different compared to those who do not. To control for this time effect, we include in our analysis the time band of the day when the activity was done, and its square, measured in 1-hour time bands (e.g., 12-1 am, 1-2 am...).

\section{Relationship between volunteering and daily happiness}

In this Section, we study the relationship between voluntary activities and daily happiness, by analyzing the relationship between feelings reported by the respondent and participation in voluntary activities on the same day. The large number of randomly selected episodes provides us with a solid framework for the analysis of this relationship. We estimate Ordinary Least Squared (OLS) models of the happiness measure (net-affect and u-index) associated with episodes as follows: ${ }^{8}$

$$
\mathbf{E}_{\mathrm{ij}}=\boldsymbol{\alpha}+\boldsymbol{\beta} \text { Voluntary }_{\mathrm{i}}+\boldsymbol{\gamma} \mathbf{X}_{\mathrm{i}}+\mathrm{\partial Day}_{\mathrm{i}}+\varepsilon_{\mathrm{ij}}
$$

where $E_{i j}$ represents the happiness measure of individual “i” in episode “j”, Voluntary ${ }_{i}$ is a dummy variable that indicates whether respondent "i” engaged in any civic/voluntary activity (1) or not (0) during the day. Thus, Voluntary $y_{i}$ takes value " 1 " if we observe positive time devoted to voluntary activities in the diary of respondent “ $i$ ”, and value " 0 ” if we do not observe

\footnotetext{
${ }^{8}$ In our regressions, we will assume that happiness measures are cardinal, an interpretation that is common in the literature on well-being (Ferrer-i-Carbonell and Frijters, 2004).
} 
time devoted to such activities. We have also estimated our models including the time devoted to voluntary activities throughout the day, measured in hours per day. According to the previously hypothesized relationship between feelings and voluntary activities, we should expect $\beta>0$ for the net-affect (larger values indicate greater differences between happiness and negative feelings), and $\beta<0$ for the u-index (happiness overcomes the feelings of stress, tiredness, sadness, pain). $X_{i}$ represents a vector of socio-demographic characteristics, while $\varepsilon_{i j}$ represents the error terms.

The window length used in the ATUS, as in other time use surveys, may lead to measurement errors in the volunteering behavior of individuals, since individuals are asked what they did on the previous day, and it may well be that individuals do voluntary activities weekly or monthly, but did no voluntary activities on the day before the survey. Thus, the shortness of the reference period for time diary studies potentially limits their usefulness for estimating the distribution of activities across populations, and the relationship between activities and daily happiness. Frazis and Stewart (2012) show that OLS models are preferred in the analysis of time-allocation decisions, compared to tobit models, as the latter yield biased results. Gershuny (2012) argues that traditional diary studies can still produce accurate estimates of mean times in activities for samples and subgroups, at least in the short-run. Foster and Kalenkoski (2013) compare estimation results from OLS and tobit models on childcare time, and they obtain almost identical results. Thus, we rely on OLS linear models.

We further estimate a Random-Effects (RE) linear model to take into account the scaling effect of individuals (Kahneman and Krueger, 2006). This implies that individuals may have a different conception of what the scale of measurement really refers to, or may interpret the scale differently. We estimate the following equation:

$$
\mathrm{E}_{\mathrm{ij}}=\alpha_{\mathrm{i}}+\beta \text { Voluntary }_{\mathrm{i}}+\gamma \mathrm{X}_{\mathrm{i}}+\partial_{\mathrm{Day}}+\varepsilon_{\mathrm{ij}}
$$

where $E_{i j}$ represents the feeling of individual “i” in episode “j”, and $\alpha_{i}$ represents the individual effect. The time variation needed to estimate a panel data model is given by the fact that each respondent has 3 episodes, and each episode may be of a different nature (e.g., leisure, personal care, housework), which gives sufficient variation to estimate the model.

\section{Results}

Table 3 shows the results of estimating Equations (1) and (2) on participation in voluntary activities throuought the day. Columns (1) and (3) refer to OLS models for the net-affect and uindex respectively, considering all activities. Columns (2) and (4) refer to RE models for the net-affect and u-index respectively, considering all activities. We observe a positive association 
between the net-affect and participation in voluntary activities on the diary day, and a negative association between the u-index and participation in voluntary activities on the diary day, with these associations being statistically significant at standard levels. Participation in voluntary activities on the day of the diary is associated with an increase and a decrease of 0.198 and 0.029 in the net-affect and the u-index, respectively, representing an increase and a decrease of 7 and 13 percent in the overall values. When we consider posible scaling effects, we observe that in the RE models, participation in voluntary activities on the day of the diary is associated with an increase and a decrease of 0.285 and 0.035 in the net-affect and the u-index, respectively, representing an increase and a decrease of 10 and 16 percent in the overall values. Hence, we find that $\beta>0$ for the net-affect and $\beta<0$ for the $\mathrm{u}$-index, which is consistent with the hypothesis that voluntary activities are positively related to the daily happiness of individuals.

In the analyzed relationship, it could be that those who devote time to voluntary activities obtain more daily happiness from their voluntary activities, as seen in Table 2, but in the other activities they report similar levels of daily happiness. Thus, we now estimate the same four models, excluding all episodes that were voluntary activities (we exclude 459 episodes). Columns (5) and (7) refer to OLS models for the net-affect and u-index respectively, excluding episodes of voluntary activities. Columns (6) and (8) refer to RE models for the net-affect and u-index respectively, excluding episodes of voluntary activities. We observe that, for both the net-affect and u-index, we obtain lower, but still statistically significant, positive and negative associations with participation in voluntary activities on the day of the diary. Thus, the positive association between voluntary activities and increased daily happiness is still present, even if we exclude episodes of voluntary activities from the analysis. The results point toward voluntary activities increasing the happiness obtained during non-voluntary activities, which would be consistent with the consumption motive of volunteering, as it seems to increase the contemporaneous utility of individuals.

Table 4 shows the results when we estimate our models considering the duration of voluntary activities. In this case, we use an indicator of participation in voluntary activities that measures the hours spent in voluntary activities during the diary day. Here results are less clear cut, as we only obtain statistically significant coefficients of voluntary time in the case of the net-affect when we include voluntary activities in the regressions. Neither the u-index in all cases, nor the net-affect when we exclude voluntary activities, present a statistically significant association with time in voluntary activities. Thus, while participation in voluntary activities seems to be positively related to daily happiness, the time in voluntary activities is not, which can be explained by the fact that activities present diminishing marginal utility, at some point Gerhuny (2013), indicating that "prolonged exposure to highly enjoyable daily activities does 
not always foretell higher levels of cumulative subjective well-being, which is associated with balanced use of time rather than increased participation in individual activities” (Zuzanek and Zuzanek, 2014, pp. 1). Thus, for the rest of our analysis we will focus on participation in voluntary activities only.

\section{Religion, working days, and daily happiness}

Various studies have highlighted the link between religion/religiosity and happiness. For instance, Helliwell (2003) finds greater life satisfaction associated with church attendance of once, or more often, a week. In Eastern Europe, Hayo (2004) finds similar results, and using ESS data Clark and Lelkes (2005) report that church attendance of at least once a month is sufficient for an effect on life satisfaction. Furthermore, as shown in Figure 1, a disproportionate share of voluntary activities take place on Sunday, which happens to be a day of high church attendance for religious individuals in the United States. If we consider the distribution of individuals in our sample according to whether they went to church or places or worship during the diary day, the greater proportion of individuals going to church is obtained on Sundays (see Figure 2). We find a positive correlation between the probability of participation in voluntary activities and the probability of going to church or a place of worship during the day $(\mathrm{R}=0.394$, $\mathrm{p}<0.01)$. Thus, it could be that people who do voluntary activities during the day also go to church or places of worship, and thus the greater daily happiness experienced by those who volunteer can be explained to some extent by the fact that they went to church. Thus, we need to net out the relationship between voluntary activities and daily happiness from the effect of religion or participation in religious activities, given that these activities have been shown to be in the third position in terms of daily happiness (e.g., overall net-affect and u-index of 4.007 and 0.127 , respectively). We have carry out three different analyses to deal with the issue of religion/religious activities, and we obtain consistent results, indicating that these are not driven by religion.

First, we have created a dummy variable to indicate whether the diary corresponds to week days (1), or to weekend (0). The reason is that those who report going to the church on the day of the survey, $13.62 \%$, did so on Saturday, and $69.65 \%$ did so on Sunday; thus, those who went to the church did so on the weekend in $83.27 \%$ of cases. If religious activities drive the difference in daily happiness between volunteers and non-volunteers, we should expect to find a closer association between participation in voluntary activities and daily happiness on the weekend. Thus, we include the interaction between participation in voluntary activities and the weekday dummy, to see if the difference between volunteers and non-volunteers varies at the weekend. Panel A of Table 5 shows the results of estimating Equations (1) and (2) when we include voluntary activities in the regressions (Columns (1) to (4)), and when we exclude 
voluntary activities from the regressions (Columns (5) to (8)). ${ }^{9}$ We find that individuals obtain lower daily happiness (a lower net-affect and a higher u-index) during the week, consistent with the fact that individuals work normally during these days, while they have more leisure time on weekends. However, we find no differential association between voluntary activities and daily happiness according to the weekend/week day distinction, and thus no evidence of a weekend effect.

Second, we have modified our dependent variable, and we now include religious activities as part of voluntary activities. Thus, we have created a dummy variable to indicate participation in voluntary activities and/or religious activities. If the association between voluntary activities and daily happiness is driven by religious activities, the inclusion of the latter should lead to almost identical results, compared to the results considering voluntary activities only (Table 3). Results are shown in Panel B of Table 5. We obtain statistically significant coefficients for all of our regressions. It is important to note that the coefficients are larger compared to the coefficients shown in Table 3, where we only include participation in voluntary activities, indicating that when we include religious activities in our definition of voluntary activities, we obtain greater differences in the daily happiness of individuals, consistent with religious activities providing a high level of happiness (see Table 2).

Third, we have controlled for whether the individual went to church at any time during the day (1) or not (0), including this variable in the regressions. We have also included an interaction term between participation in voluntary activities and church attendance. If this interaction term is statistically significant, it would mean that church attendance, and the religiosity of individuals, is important in the relationship between daily happiness and voluntary activities. Results are shown in Panel C of Table 5, and we still find a statistically significant relationship between voluntary activities and daily happiness. The interaction term is not statistically significant at standard levels, indicating that religion/religiosity does not drive an association between voluntary activities and daily happiness.

Another posible channel through which participation in voluntary activities and daily happiness could be related is market work. It could be that those who volunteer on the day of the survey do not have to work, or work fewer hours on that day, compared to non-volunteers. In fact, the analysis of the diaries considering whether the diarist devoted some time to market work, or not, on the day of the survey, shows that $65 \%$ of those who devoted time to voluntary activities did so on non-working days. On a day off, they can enjoy other activities, like personal care or leisure, much more than on a workday, and the fact that individuals do not have market work on that day indicates that individuals have the freedom to choose any activity they

\footnotetext{
${ }^{9}$ Given that we control for whether the diary corresponds to the weekend, or to weekdays, we do not include daydummy variables.
} 
want, and thus some may choose to volunteer while others may choose to have more leisure. Thus, we propose to analyze differences between volunteers and non-volunteers on nonworking days (i.e. no time on market work and commuting), to see if there are differences in the daily happiness according to participation in voluntary activities. Panel D of Table 5 shows the results of estimating Equations (1) and (2) on daily happiness, considering whether the individual participated in voluntary activities during the non-working day. Our main results are maintained, that those who volunteer on their days off report a higher experienced utility. We interpret these results as that, despite volunteers devoting less time to market work during the day, the difference does not depend on the fact that people who volunteer had to work less, or did not work at all, on the particular day, and thus we disregard this possible channel.

\section{Accounting for reverse causality between volunteering and daily happiness}

One problem when analysing the effects of voluntary activities on daily happiness is that of reverse causality (people volunteer more when they are happy) and simultaneity biases (some third factor leads to more volunteering and more daily happines). Many prior studies are correlational as they do not take into account these problems, and those studies that have done so have found that the effect of volunteering on happiness decreases. In this Section, we develop an Instrumental Variable (IV) estimation to deal with the issue of reverse causality, to see if those who are happier are also more likely to participate in voluntary activities.

To that end, we regress the possible endogenous variable Voluntary $_{i}$ included in Equations (1) and (2) on a set of excluded $\left(I V_{i}\right)$ and included instruments $\left(X_{i}\right.$, and $\left.D_{a y}\right)$. The 2equation system can be written as follows:

$$
\begin{aligned}
& \mathbf{E}_{\mathbf{i j}}=\boldsymbol{\alpha}_{\mathbf{1}}+\boldsymbol{\beta}_{\mathbf{1}} \text { Voluntary }_{\mathbf{i}}+\boldsymbol{\gamma}_{\mathbf{1}} \mathbf{X}_{\mathbf{i}}+\partial_{1} \operatorname{Day}_{\mathbf{i}}+\varepsilon_{\mathrm{ij}} \\
& \text { Voluntary }_{i}=\alpha_{\mathbf{2}}+\beta_{\mathbf{2}} I V_{i}+\gamma_{\mathbf{2}} X_{i}+\partial_{\mathbf{2}} D a y_{i}+\phi_{i j}
\end{aligned}
$$

where $E_{i j}$ represents the happiness measure of individual “i” in episode “j”, Voluntary ${ }_{i}$ is a dummy variable that indicates whether respondent "i" engaged in any voluntary activity (1) or not (0) during the day, $X_{i}$ represents a vector of socio-demographic characteristics, and $\varepsilon_{i j}$ represents the error terms. We additionally estimate Equation (4) where we regress participation in voluntary activities on a set of instruments, and the other socio-demographic characteristics included in Equation (3). Regarding the instruments, they must fullfill rank and orthogonality conditions, such that 1) the instruments must be correlated with the variables to be instrumented, and 2) the instruments must be uncorrelated with whatever is not observed that is a determinant of $\mathbf{E}_{\mathrm{ij}}$ (Greene, 2008; Angrist and Pischke, 2009; Woolridge, 2010). Intuitively, a reliable instrumental variable must be first theoretically justified and statistically correlated, 
after controlling for all other exogenous regressors, with the endogenous variable of interest, and it must be exogenous to all other important and unobserved factors (i.e. uncorrelated with the disturbance term in the outcome equation).

The literature has identified differences and changes in laws as suitable instruments. Angrist and Krueger (1991) instrumented education using compulsory schooling laws, or state laws on minimum legal drinking age, and the state beer tax to instrument substance use (see French and Popovici, 2011, for a review). Under this framework, we use cross-state differences in laws on deductions for charitable gifts as our main instrument. We consider that cross-state differences in laws on deductions for charitable giving allow us to identify participation in voluntary activities, despite that the direction of the relationship is unknown a priori. In states that have an income tax and a charitable deduction, there is a greater incentive to donate to charity, but the opportunity cost of time is also lower because the income tax reduces the opportunity cost of time, assuming some of the incidence falls on the worker. In states with an income tax but without deduction for charity, the reduction in opportunity cost of time would be present, but not the incentive to make charitable contributions (Gale and Scholz, 1994).

We use the information on which states have a deduction for charitable contributions, and which ones have no such deduction, obtained from the National Bureau for Economic Research (http://users.nber.org/ taxsim/charity-state/). From this web site, we obtain an indicator for charitable deductions that takes value " 1 " for deduction, value " 0 " for none, and "- 1 " for no tax due, witn this information being available at the state level for the year 2010, the year of reference. We propose this indicator as an instrument for voluntary activities. ${ }^{10}$ Looking at the Spearman's rank correlation between participation in voluntary activities and this instrument, we observe that Spearman's rho is 0.0266 , and the null hypothesis that the variables are independent is rejected $(\mathrm{p}<0.01)$. Thus, we can assume that the two variables are correlated. On the contrary, and considering the relationship between the net-affect and u-index, on the one hand, and the instrument, on the other, the Spearman's rho are 0.0051 and -0.0086 respectively, thus accepting the null hypothesis that the the net-affect $(\mathrm{p}=0.429)$ and $u$-index $(\mathrm{p}=0.1681)$ are independent of the instrument.

Table 6 shows the results of estimating equations (3) and (4), for both the net-affect and uindex. ${ }^{11}$ We present estimations according to two types. Columns (1) and (2) present results for the net-affect and u-index when we use the Two-Stage Least Squares (2SLS) estimator. Columns (3) and (4) present results for the net-affect and u-index when we use the Generalized Two-Stage Least Squares random-effects (G2SLS) estimator from Balestra and Varadharajan-

\footnotetext{
${ }^{10}$ See table A3 in the Appendix for a description of the values of the indicator for each state.

${ }^{11}$ We present results only for Equation (4), which is the equation of interest. Results for the first stage regressions are available upon request.
} 
Krishnakumar (1987). The first-stage estimates of the IV in the bottom panel show that the instrument is statistically different from zero at conventional levels in all regressions. Additionally, if the instrument fails to explain a sufficient amount of the variation in the endogenous regressor, it can generate IV estimates with large standard errors, as well as lead to large asymptotic biases (Bollen et al., 1995; Bound et al., 1995; Staiger and Stock, 1997), and thus we have to look at the "weakness" of the instrument (Stock et al., 2002). An F-statistic above 10 is commonly viewed as the threshold (Staiger and Stock, 1997; Stock et al., 2002), and in our case the F-Statistic in the 2SLS is well above this value (27.05).

We observe that coefficients for participation in voluntary activities are not statistically significant at standard levels in any of the columns in Table 6. Thus, once we take into account the reverse causality, we find that volunteering has no causal effect on the daily happiness of individuals. The interpretation of these results is that voluntary activities do not make individuals happier, but that happier individuals are more likely to participate in voluntary activities, in such a way that there is selection into participation in voluntary activities.

In another set of regressions, we have instrumented participation in voluntary activities using the number of nonprofit institutions per 10,000 inhabitants at the state level, for the year 2010 (information obtained from the National Center for Charitable Statistics http://nccsweb.urban.org/). We consider this instrument is able to capture differences at the state level in the level of altruism, with a larger number of institutions indicating that the level of altruism is higher in the state, and we suppose that a higher level of altruism is related to a greater participation in voluntary activities. Columns (5) and (6) present results for the net-affect and u-index when we use the (2SLS) estimator, and Columns (7) and (8) present results when we use the G2SLS random-effects estimator.

The first-stage estimates of the IV in the bottom panel show that both instruments are statistically different from zero at conventional levels in all the regressions. Additionally, the FStatistic in the 2SLS is 14.94, above the threshold value of 10. Furthermore, when we have two instruments, we can apply Sargan's test of overidentifying restrictions in the 2SLS estimator. The joint null hypothesis is that the instruments are valid instruments (i.e., uncorrelated with the error term), and that the excluded instruments are correctly excluded from the estimated equation (Hayashi, 2000). Under the null hypothesis, the test statistic is distributed as a ${ }^{x^{2}}$ (1). In our case, the values of the Sargan' statistic are 0.103 and 1.452 for the net-affect and u-index, respectively, which leads us to accept the null hypothesis of the validity of instruments at standard levels ( $\mathrm{p}=0.749$ and $\mathrm{p}=0.228$ for the net-affect and the u-index, respectively). We observe that the coefficients for participation in voluntary activities are not statistically significant at standard levels in any of the columns in Table 6 . Thus, once we take into account 
reverse causality, we find that participation in voluntary activities has no causal effect on the happiness of individuals.

Finally, we have done an analysis where we consider only those who volunteer during the day. If the anticipation of volunteering makes people happy, we should find that volunteers achieve greater daily happiness during activities prior to volunteering. If volunteers are happier as a result of volunteering, we should obtain greater daily happiness via post-volunteering activities. Thus, we compare the levels of happiness of before and after the voluntary act, controlling for whether the non-voluntary activity of reference was done after any voluntary activity (reference) or before. After estimating equations (1) and (2), we find no evidence of differences between activities done before and after voluntary activities (results available upon request), which we interpret as evidence that voluntary activities do not affect daily happiness, but happier individuals are more likely to participate in voluntary activities, a result that is consistent with the IV results.

\section{Voluntary activities: “time-composition" and "personality" effects.}

Given the previously reported positive association between voluntary activities and daily happiness, in this Section we decompose the difference in daily happiness between volunteers and non-volunteers in two components: the "time-composition" and "personality" effects. The former captures the difference in the daily happiness that can be attributed to differences in the distribution of activities during the day. To the extent that different activities provide different levels of daily happiness to individuals, including voluntary activities that have been shown to be ranked among the five most enjoyable, the difference in daily happiness between volunteers and non-volunteers can be explained because those who volunteer during the day may differ in how they spend their time, compared to those who do not volunteer. The latter captures the variations in daily happiness that can be attributed to differences in happiness obtained while engaged in similar activities. It could be that volunteers and non-volunteers report different levels of daily happiness when engaged in the same activities during the day. Such differences are defined at the individual level, as they depend on inter-personal differences in same activities, and thus we call this the "personality" effect.

We first analyze differences in the time devoted to different activities and the associated net-affect and u-index, broken down by participation in voluntary activity, shown in Table $7 .{ }^{12}$

\footnotetext{
12 The net-affect and $u$-index are computed at the episode level, while the time devoted to each of the activities is computed at the diary level (i.e. for each individual, we sum the time devoted to the reference activity during the day, and compute the overall time devoted to this activity by all individuals in the reference sample). The time devoted to the different activities is measured in minutes per day. The classification of activities corresponds to the basic classification of Aguiar and Hurst (2007) and Gimenez-Nadal and Sevilla (2012). Though sleeping is not reported, we computed the time devoted to it to see if there is any difference between the two groups of individuals.
} 
Activities are sorted following the ranking in the net-affect shown in Table 2, although we place voluntary activites in the first position. We compute the difference between the two groups in the net-affect, the u-index, and the time devoted to each activity, and we compute the p-value of that difference (t-type test of equality of means), where a p-value lower than 0.05 indicates that the difference between the two groups is statistically significant at standard levels.

Regarding the time devoted to the different activities, we find that volunteering individuals take up 102.733 minutes during the day, and that, compared to individuals who do not volunteer, they devote more time to out-of-home leisure (8.881 more minutes), religious activities (0.115 more minutes), teaching child care (1.790 more minutes), basic child care (7.477 more minutes), cooking and meals (4.011 more minutes), shopping (3.502 more minutes) and housework (7.187 more minutes). On the contrary, individuals who volunteered during the day of the survey devote less time to sports/exercise (4.609 fewer minutes), gardening/pet care (4.189 fewr minutes), leisure travel (2.524 fewer minutes), TV watching (58.645 fewer minutes), commuting/work related activities (9.045 fewer minutes), main work (109.288), job search (2.648 fewer minutes) and own medical care (4.010 fewer minutes). Thus, in comparison to individuals not doing voluntary activities, those who volunteer spend around 120 more minutes on voluntary activities, out of home leisure, religious activities, supervisory child care and basic childcare, while they employ 177 fewer minutes doing market work, activities related to work, and TV watching. According to Table 2, the former group of activities produce higher levels of individual happiness, while the latter group of activities produce lower levels of happiness. Thus, this "composition" effect may explain the differences in the average daily happiness of those who devote time to voluntary activities.

If we look at differences in the net-affect and the u-index between the two groups, we find that for both measures, individuals volunteering during the day of the survey obtain a higher level of happiness from commuting/work related activities (differences in the net-affect and uindex are 0.406 and -0.084) and housework (differences in the net-affect and u-index are 0.744 and -0.122), while they obtain less happiness from supervisory child care (differences in the netaffect and u-index are -1.583 and 0.146). Thus, it seems that volunteers obtain a different level of daily happiness while engaged in commuting/work related activities, housework, and supervisory child care, pointing to a "personality" effect: when engaged in similar activities, those who devoted time to voluntary activities during the day of the survey feel happier than those who did not.

To disentagle the extent to which each of the effects contributes to the previously reported differences in daily happiness between the two groups, we follow Knabe et al. (2010) by decomposing the difference in our two measures of daily happiness by a simulation. First, we calculate how the average experienced utility of all volunteers would change if they did no 
voluntary activities, under the assumption that they experience the average utility of a nonvolunteer in all activities, but maintain the time schedule they had when they were doing voluntary activities (i.e. well-being as counterfactual). ${ }^{13}$ The difference between the experienced utility while doing voluntary activities and its value after this hypothetical change corresponds to the "personality" effect; the remaining difference in the experienced utility associated with not volunteering can then be assigned to the "time-composition" effect.

The decomposition of these two effects, using the well-being measures as counterfactual, is shown in Panel A of Table 8. The net-affect for those who devote time to voluntary activities, using the net-affect values of those who do not volunteer, is 2.907 (see Table A4 for details of calculations), which when compared with the real value of 3.113 of the net-affect of this group, indicates that the "personality" effect accounts for 0.179 of the 0.385 difference in the netaffect. Thus, of the 0.385 difference in the net-affect between the two groups, the "personality" effect explains $46 \%$ (0.179 out of 0.385 ), while the "time-composition" effect explains $54 \%$ (0.206 out of 0.385 ) of the difference. We find that the u-index for those who volunteer, using the u-index values of those who do not, is 0.245 , which when compared with the real value of 0.194 of the u-index of this group indicates that the "personality" effect accounts for -0.020 of the -0.071 difference in the u-index. Thus, of the -0.071 difference in the u-index between the two groups, the "personality" effect explains $28 \%(-0.020$ out of -0.07$)$ while the "timecomposition" effect explains $72 \%(-0.051$ out of -0.07$)$ of the difference. If, rather than considering individuals who volunteer as the reference group, we consider those who do not, and use the affective measures of individuals who do volunteer as the counterfactual (Panel B), we observe that for the net-affect and the u-index, the "personality" effect accounts for 0.042 and -0.018 of the difference between the two groups, respectively, representing $11 \%$ and $25 \%$ of the difference.

In sum, we find that the difference in daily happiness between volunteers and nonvolunteers can be decomposed into two components: the "personality" and "time-composition" effects. While the "time-composition" effect is large, as it explains between 54\% and 89\% of the difference in daily happiness between the two groups, the "personality" effect on other activities is smaller but still significant, as it explains between $11 \%$ and $46 \%$ of the observed difference in daily happiness during the day.

\footnotetext{
${ }^{13}$ Here we must consider that the time devoted to sleep is slightly different, although the difference is not statistically significant at standard levels, between the groups. Rather than considering the total time devoted to the activity, we multiply by the net-affect/u-index of reference for each activity, and then divide the sum of the product by the waking time, to obtain a measure of experienced utility during the day. We directly divide the average time devoted to the activity divided by the waking time (820 and 880 minutes per day for volunteers and non-volunteers, respectively) and multiply for the corresponding affective measure. Since we do not observe experienced utility ratings for voluntary activities for non-volunteers, we assume that volunteers maintain their original values.
} 
We offer a decomposition of the two channels that may help to explain the difference in daily happiness between volunteers and non-volunteers, on a daily basis. However, this decomposition only provides lower and upper limits of the part each effect is able to explain. In the case of the "personality" effect, while $11 \%$ may seem a small effect, $46 \%$ is significant. Additionally, we do not know what factors comprise this "personality" effect (social networks, extraversion, motivations...). Additionally, the "time-composition" effect shows that volunteers devote less time to market work activities, which may indicate that they also work less. However, as shown in Section 5, this difference does not depend on the day (working or nonworking).

\section{Conclusions}

Working for no pay is a widespread economic activity whose significance is not yet fully understood. In the United States, around 50\% of all adults do some kind of volunteering, equivalent to five million full-time jobs (Anheier and Salamon, 1999). Thus, understanding the reasons why individuals do such work has been the focus of a significant amount of research. In this paper, we analyze voluntary activities, with a focus on how participation of this type is associated with individual happiness.

Using the Well Being Module of the American Time Use Survey (ATUS) 2010, we find that participation in voluntary activities is positively associated with the daily happiness of individuals, as individuals who volunteer report higher values of the net-affect, and lowervalues of the u-index. These results are maintained when we control for the scaling effect of individuals, and when we exclude episodes of voluntary activities from the analysis, and the variations are not driven by participation in religious activities. Using cross-state variations regarding tax deductions for charitable contributions as our main instrument, we apply an IV estimation to deal with the issue of reverse causality, and our results indicate that happier individuals are more likely to participate in voluntary activities. Finally, we decompose the difference in daily happiness between volunteers and non-volunteers in a "time-composition" and "personality" effect, and find that the "personality" effect explains between 11\% and $46 \%$ of the difference in happiness between volunteers and non-volunteers during the day.

To the extent that happier individuals are more likely to volunteer, it may be of interest for employers, given existing research that has found a positive relationship between happiness and worker productivity (Freeman, 1978; Bockerman and Ilmakunnas, 2012; Oswald et al., 2014). Studying the extent to which volunteers are more productive in the firm posits an interesting line of future research. If volunteers are more productive workers, employers may consider this voluntary work as a marker for productivity. However, volunteers devote less time to market 
work, an effect that appears to be negative in terms of productivity. It would be of interest to see which effect is dominant. Furthermore, the "personality" effect may account for a significant part of the difference between volunteers and non-volunteers. Analyzing the extent to which volunteers differ in their non-observable characteristics (motivations, social context, social networks, trust...) may be of interest, as in this paper we offer both lower and upper bounds of the effect. Additionally, the fact that volunteers devote comparatively less time to watching TV may help media channels to focus their commercial campaigns and programming according to audience demographics. We leave these issues for future research.

\section{REFERENCES}

Aguiar, M., and E. Hurst (2007). "Measuring Trends in Leisure: The Allocation of Time over Five Decades,” Quarterly Journal of Economics 115: 969-1006.

Andreoni, J. (1989). "Giving with impure altruism: Applications to charity and ricardian equivalence,” Journal of Political Economy 97: 1447-1458.

Andreoni, J. (1990). "Impure altruism and donations to public goods: A theory of warm-glow giving,” The Economic Journal 100: 464-477.

Angrist, J.D., and A.B. Krueger (1991). "Does Compulsory School Attendance Affect Schooling and Earnings?” Quarterly Journal of Economics 106: 979-1014.

Angrist, J.D., and J.S. Pischke (2009). Mostly Harmless Econometrics: An Empiricist's Companion. Princeton University Press.

Ariely, D., A. Bracha and S. Meier (2009). "Doing good or doing well? Image motivation and monetary incentives in behaving pro-socially,” 99: 544-555.

Balestra, P., and J. Varadharajan-Krishnakumar (1987). "Full Information Estimation of a System of Simultaneous Equations with Error Component Structure,” Econometric Theory 223-246.

Becchetti, L., A. Pelloni and F. Rossetti (2008). "Relational goods, sociability, and happiness,” Kyklos 61: 343-363.

Becker, G. S. (1974). “A theory of social interactions,” Journal of Political Economy 82: 10631093.

Bekkers, R. (2010). "Who gives what and when? A scenario study of intentions to give time and money,” Social Science Research 39: 369-381.

Bénabou, R., and J. Tirole (2005). "Incentives and prosocial behavior," National Bureau of Economic Research No. w11535

Bianchi S., M. Milkie, L. Sayer and J.P. Robinson (2000). "Is anyone doing the housework? Trends in the gender division of household labor,” Social Forces 79: 191-228.

Binder, M., and A. Freytag (2013). "Volunteering, subjective well-Being and public policy," Journal of Economic Psychology 34: 97-119. 
Bjørnskov, C. (2007). “The multiple facets of social capital,” European Journal of Political Economy 22: 22-40.

Bockerman, P., and P. Ilmakunnas (2012). "The job satisfaction-productivity nexus: A study using matched survey and register data," Industrial and Labor Relations Review 65: 244262.

Bollen, K.A., D.K. Guilkey and T.A Mroz (1995). "Binary outcomes and endogenous explanatory variables: tests and solutions with an application to the demand for contraception use in Tunisia,” Demography 32: 111-131.

Bonke, J. (2005). "Paid work and unpaid work: diary information versus questionnaire information," Social Indicators Research 70: 349-368.

Borgonovi, F. (2008). "Doing well by doing good. The relationship between formal volunteering and self-reported health and happiness," Social Science and Medicine 66: 23212334.

Bound, J., D.A Jaeger and R.M. Baker (1995). "Problems with instrumental variables estimation when the correlation between the instruments and the endogenous explanatory variable is weak,” Journal of the American Statistical Association 90: 443-450.

Brehm, J., and W. Rahn (1997). "Individual-level evidence for the causes and consequences of social capital,” American Journal of Political Science 41: 999-1023.

Brooks, A.C. (2006). Who really cares? The surprising truth about compassionate conservativism. New York: Basic Books.

Brooks, A.C. (2007). “Does giving make us prosperous?” Journal of Economics and Finance 31: 403-411.

Carpenter, J., and C.K. Myers (2010). "Why volunteer? Evidence on the role of altruism, image, and incentives,” Journal of Public Economics 94: 911-920.

Choi, N.A., and J. Kim (2011). "The effect of time volunteering and charitable donations in later life on psychological wellbeing,” Ageing and Society 31: 590-610.

Clark, A., and O. Lelkes (2005). “Deliver us from evil: Religion as insurance,” PSE, Paris.

Dolan, P., Peasgood, T., and M. White (2008). "Do we really know what makes us happy? A review of the economic literature on the factors associated with subjective well-being," Journal of Economic Psychology 29: 94-122.

Dulin, P.L., J. Gavala, C. Stephens, M. Kostick and J. McDonald (2012). “Volunteering predicts happiness among older Maori and non-Maori in the New Zealand health, work, and retirement longitudinal study,” Aging and Mental Health 16: 617-624.

Duncan, B. (1999). "Modeling charitable contributions of time and money,” Journal of Public Economics 72: 213-242

Ferrer-i-Carbonell, A., and P. Frijters (2004). "How Important is Methodology for the estimates of the determinants of Happiness?” Economic Journal 114: 641-659. 
Foster, G., and C. Kalenkoski (2013). "Tobit or OLS? an empirical evaluation under different diary window lengths” Applied Economics 45: 2994-3010.

Frazis, H., and J. Stewart (2012). "How to Think About Time-Use Data: What Inferences Can We Make About Long- and Short-Run Time Use from Time Use Diaries?” Annals of Economics and Statistics 105/106, 231-246.

Freeman, R.B. (1978). “Job satisfaction as an economic variable,” American Economic Review 68: 135-141.

Freeman, R.B. (1997). "Working for Nothing: The Supply of Volunteer Labor," Journal of Labor Economics 15: 140-166.

French, M.T., and I. Popovici (2011). "That Instrument Is Lousy! In Search of Agreement When Using Instrumental Variables Estimation in Substance Use Research,” Health Economics 20: 127-146.

Gale. W.G., and J.K. Scholz (1994). "Intergenerational Transfers and the Accumulation of Wealth,” Journal of Economic Perspectives 8: 145-160.

Gershuny, J. (2012). “Too Many Zeros: A Method for Estimating Long-term Time-use from Short Diaries,” Annals of Economics and Statistics 105/106: 247-270.

Gershuny, J. (2013). “National Utility: Measuring the Enjoyment of Activities,” European Sociological Review 29: 996-1009.

Gimenez-Nadal, J.I., and A. Sevilla (2012). "Trends in time allocation: A cross-country analysis,” European Economic Review 56: 1338-1359.

Glazer, A., and K.A. Konrad (1996). “A signaling explanation for charity,” American Economic Review 86: 1019-1028.

Gosling, S. D., P.J. Rentfrow and W.B.J. Swann (2003). “A very brief measure of the big-five personality domains,” Journal of Research in Personality 37: 504-528.

Green, W.H. (2008). Econometric Analysis. Prentice Hall.

Greenfield, E.A., and N.F. Marks (2004). "Formal volunteering as a protective factor for older adult’s psychological well-being,” Psychological Sciences and Social Sciences 59B: 258264.

Hayo, B. (2004). “Happiness in Eastern Europe,” Mimeo, Philipps University Marburg, Number $12 / 2004$

Helliwell, J.F. (2003). "How’s life? Combining individual and national variables to explain subjective well-being,” Economic Modelling 20: 331-360.

Helliwell, J.F., and R. Putnam (2004). “The social context of well-being,” Philosophical Transactions of the Royal Society London 359: 1435-1446.

Huang, J., H.M. van den Brink, and W. Groot (2009). "A meta-analysis of the effect of education on social capital," Economics of Education Review 28: 454-464. 
Juster, T. and F. Stafford (1985). Time, Goods, and Well-Being. Ann Arbor, MI: Institute for Social Research.

Kahneman, D. and A.B. Krueger (2006). "Developments in the Measurement of Subjective Well-Being,” Journal of Economic Perspectives 20: 3-24.

Kahneman, D., A.B. Krueger, D. Schkade, N. Schwarz and A. Stone (2004). "A Survey Method for Characterizing Daily Life Experience: The Day Reconstruction Method,” Science 3: 1776-1780.

Kahneman, D., P.P. Wakker and R. Sarin (1997). "Back to Bentham? Explorations of Experienced Utility,” Quartely Journal of Economics 112: 375-405.

Knabe, A., S. Rätzel, R. Schöb and J. Weimann (2010). "Dissatisfied with Life, but Having a good Day: Time-Use and Well-Being of the Unemployed,” Economic Journal 120: 867-889.

Krueger, A.B. (2007). “Are We Having More Fun Yet? Categorizing and Evaluating Changes in Time Allocation,” Brookings Papers on Economic Activity 2: 193-217.

Krueger, A.B., D. Kahneman, C. Fischler, D. Schkade, N. Schwartz, and A.A. Stone (2009a). "Time Use and Subjective Well-Being in France and the U.S." Social Indicators Research 93: 7-18.

Ladd, E.C. (1999). The Ladd Report. New York: Free Press.

Li, Y., A. Pickles and M. Savage (2005). "Social capital and social trust in Britain,” European Sociological Review 21: 109-123.

Meier, S., and A. Stutzer (2008). “Is Volunteering Rewarding in Itself?” Economica 75: 39-59.

Menchik, P.L., and B.A. Weisbrod (1987). "Volunteer labor supply,” Journal of Public Economics 32: 159-183.

Musick, M.A., and J. Wilson (2003). "Volunteering and depression: The role of psychological and social resources in different age groups,” Social Science and Medicine 56: 259-269.

Okun, M. A., J. Pugliese and K.S. Rook (2007). "Unpacking the relation between extraversion and volunteering in later life: The role of social capital,” Personality and Individual Differences 42: 1467-1477.

Omoto, A. M., M. Snyder and J.D. Hackett (2010). "Personality and motivational antecedents of activism and civic engagement,” Journal of Personality 78:1703-1734.

Onyx, J.A., and J.R. Warburton (2003). "Volunteering and health among older people: a review,” Australasian Journal on Ageing 22: 65-69.

Ostrower, F. (1997). Why the wealthy give: The culture of elite philanthropy. Princeton University Press.

Oswald, A., E. Proto and D. Sgroi (2014). "Happiness and Productivity,” Journal of Labor Economics, forthcoming.

Pichler, F. (2006). "Subjective quality of life of young Europeans. Feeling happy but who knows why?” Social Indicators Research 75: 419-444. 
Post, S. G. (2005). “Altruism, happiness, and health: It’s good to be good,” International Journal of Behavioral Medicine 12: 66-77.

Putnam, R. (2000) Bowling alone: The collapse and revival of American community. New Yourk: Simon and Schuster.

Robinson, J.P. (2014). “Gender Differences in Experiencing US Daily Life,” Psychology 5: 581-586.

Robinson, J. P., and G. Godbey (1985). Time For Life: The Surprising Ways Americans Use Their Time. University Park, Pennsylvania: Penn State University Press.

Rose-Ackerman, S. (1996). “Altruism, nonprofits, and economic theory,” Journal of Economic Literature 34: 701-728.

Rotolo, T., J. Wilson, J., and M.E. Hughes (2010). "Homeownership and volunteering: An alternative approach to studying social inequality and civic engagement," Sociological Forum 25: 570-587.

Sevilla, A., J.I. Gimenez-Nadal and J. Gershuny (2012). "Leisure Inequality in the United States: 1965-2003,” Demography 49: 939-964.

Shang, J., and R. Croson (2009). “A field experiment in charitable contribution: The impact of social information on the voluntary provision of public goods,” Economic Journal 119: 1422-1439.

Staiger, D., and J.H. Stock (1997). "Instrumental variables regression with weak instruments," Econometrica 65: 557-586.

Stock, J.H., J.H. Wright and M. Yogo (2002). "A survey of weak instruments and weak identification in generalized method of moments," Journal of Business and Economic Statistics 20: 518-529.

Szalai, A. (1972). The Use of Time. The Hague and Paris: Mouton Press.

Thoits, P.A., and L.N. Hewitt (2001). "Volunteering work and well-being," Journal of Health and Social Behaviour 42: 115-131.

Unger, S. L. (1991). “Altruism as a Motivation to Volunteer,” Journal of Economic Psychology 12: $71-100$

U.S. Bureau of Labor Statistics (2013a). http://www.bls.gov/news.release/volun.nr0.htm accessed on 22 ${ }^{\text {nd }}$ July, 2013.

U.S. Bureau of Labor Statistics (2013b). "Charts by Topic: Volunteer Activities," http://www.bls.gov/tus/charts/volunteer.htm. Accessed 03/08/13.

White, M.P., and P. Dolan (2009). "Accounting for the richness of daily activities," Psychological Science 20: 1000-1008.

Wilson, J. (2000). “Volunteering,” Annual Review of Sociology 26: 215-240.

Wilson, J. (2012). “Volunteerism research,” Nonprofit and Voluntary Sector Quarterly 41: 176212 
Wilson, J., and M.A. Musick (1997). "Work and Volunteering: The long arm of the job,” Social forces 76: 251-272.

Wooldridge, J. M. (2010). Introductory Econometrics: A Modern Approach. Mason, OH: Thomson South-Wester

Yee-Kan, M. (2008). "Measuring housework participation: the gap between "stylised" questionnaire estimates and diary-based estimates,” Social Indicators Research 86: 381-400.

Zuzanek, J., and T. Zuzanek (2014). "Of Happiness and of Despair, Is There a Measure? Time Use and Subjective Well-being,” Journal of Happiness Studies, forthcoming. 
Figure 1. Participation in voluntary activities, by day of the week.

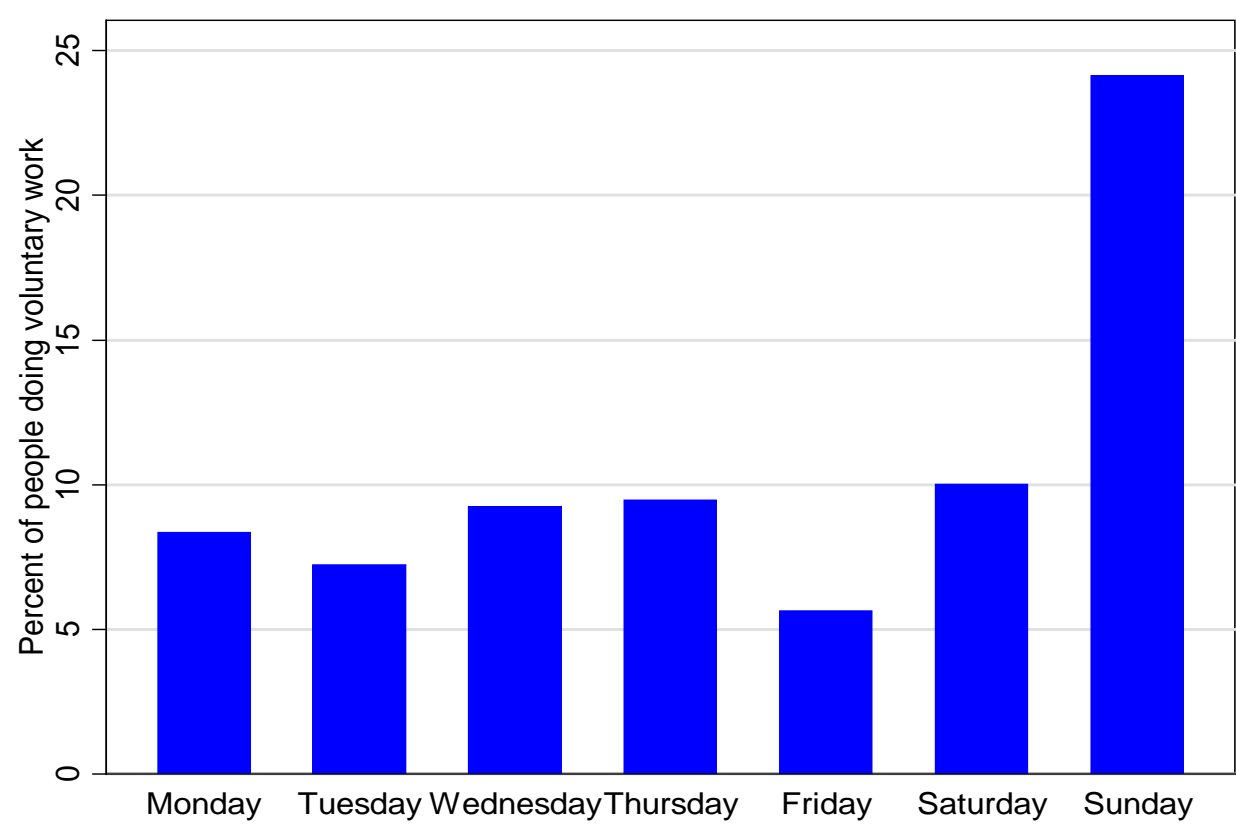

Note: Sample consists of episodes from non-retired/non-students respondents between 2165 years old from the ATUS 2010 Well-being Module. Partication in voluntary activities defined as a dummy variable that takes value " 1 " if the respondent devoted any time to voluntary activities during the day of the survey, and value " 0 " otherwise.

Figure 2. Distribution of days of the week for church attendance

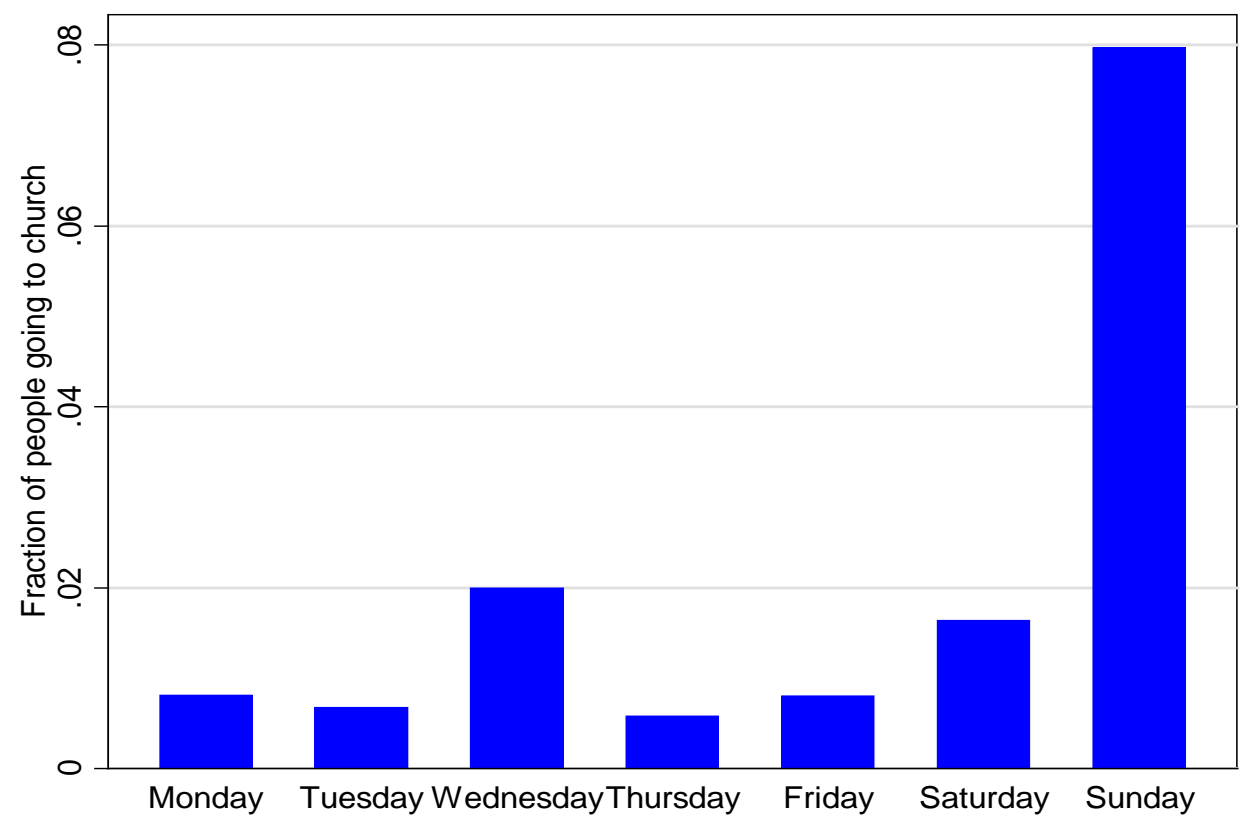

Note: Sample consists of episodes from non-retired/non-students respondents between 2165 years old from the ATUS 2010 Well-being Module. Information on church attendance is obtained using the information on the places where the activity took place. We consider the individual went to church if at least one activity was done in church or places of worship. 
Table 1. Summary statistics for experienced utility

\begin{tabular}{|c|c|c|c|c|c|c|c|c|}
\hline & \multicolumn{2}{|c|}{ (1) } & \multicolumn{2}{|c|}{$(2)$} & \multicolumn{2}{|c|}{ (3) } & \multirow{2}{*}{$\begin{array}{l}\text { (4) } \\
\text { Diff }\end{array}$} & \multirow[b]{2}{*}{ P-Value Diff } \\
\hline & \multicolumn{2}{|c|}{ All the episodes } & \multicolumn{2}{|c|}{$\begin{array}{c}\text { Episodes with } \\
\text { volunteering }\end{array}$} & \multicolumn{2}{|c|}{$\begin{array}{c}\text { Episodes without } \\
\text { volunteering }\end{array}$} & & \\
\hline & Mean & $\underline{S D}$ & Mean & $\underline{S D}$ & Mean & $\underline{S D}$ & & \\
\hline Net Affect & $\overline{2.768}$ & $(2 . \overline{38} 4)$ & $\overline{3.113}$ & $(2 . \overline{36} 4)$ & $\overline{2.728}$ & $(2 . \overline{38} 3)$ & 0.385 & $(<0.01)$ \\
\hline U Index & 0.261 & (0.439) & 0.219 & $(0.413)$ & 0.266 & $(0.442)$ & -0.047 & $(<0.01)$ \\
\hline$N$ observations & \multicolumn{2}{|c|}{25,604} & \multicolumn{2}{|c|}{3,235} & \multicolumn{2}{|c|}{22,369} & & \\
\hline
\end{tabular}

Note: Sample consists of episodes from non-retired/non-students respondents between 21-65 years old from the ATUS 2010 Well-being Module. Standard deviations in parentheses. Means are computed using the original weights included in the survey. Column (1) shows means and standard deviations for the net-affect and u-index for all episodes. Column (2) shows mean and standard deviations for the net-affect and the u-index for episodes of respondents reporting positive time in volunteer activities throughout the diary day. Column (3) shows mean and standard deviations for the net-affect and the u-index for episodes of respondents reporting no time in volunteer activities throughout the diary day. Column (4) shows the differences in mean values of the net-affect and the u-index for episodes from individuals devoting and not devoting time to volunteer activities throughout the day, and Column (5) shows the p-value of the difference based on a t-test type test.

Table 2. Overall experienced utility, by activity type

\begin{tabular}{lcc}
\hline & $(1)$ & $(2)$ \\
\cline { 2 - 3 } Activities & Net Affect & U Index \\
\hline Supervisory child care & 4.548 & 0.064 \\
Out-of-home leisure & 4.195 & 0.087 \\
Religious activities & 4.007 & 0.127 \\
Teaching child care & 3.637 & 0.162 \\
Voluntary activities & 3.483 & 0.194 \\
Sports/exercise & 3.415 & 0.159 \\
Basic Child care & 3.400 & 0.195 \\
Eating & 3.346 & 0.177 \\
At-home leisure & 3.274 & 0.205 \\
Reading/listening & 3.130 & 0.202 \\
Gardening/pet care & 3.101 & 0.223 \\
Leisure travel & 3.017 & 0.198 \\
Personal care & 2.986 & 0.194 \\
Cooking, meals & 2.977 & 0.221 \\
Adult care & 2.925 & 0.290 \\
Writing/paperwork & 2.802 & 0.270 \\
TV watching & 2.693 & 0.264 \\
Shopping & 2.650 & 0.286 \\
Commuting/work related & 2.645 & 0.266 \\
Other housework & 2.619 & 0.270 \\
Education & 2.372 & 0.275 \\
Housework & 2.352 & 0.291 \\
Main work & 2.271 & 0.328 \\
Home/car maintenance & 2.095 & 0.308 \\
Job search & 1.539 & 0.500 \\
Own medical care & -0.070 & 0.740 \\
\hline No: Sanple & & \\
\hline & &
\end{tabular}

Note: Sample consists of non-retired/non-students respondents between 21-65 years old from the ATUS 2010 Well-being Module. Activities are ranked from the highest to the the lowest net-affect. Classification of activities is shown in Table A1 in the Appendix. Overall values are computed using the original weights of the survey, which take into acccount the duration and are adjusted to compensate for the activities that were underrepresented in the WB module because of the exclusion error in the selection process. 
Table 3. Results for participation in voluntary activities

\begin{tabular}{|c|c|c|c|c|c|c|c|c|}
\hline & $(1)$ & (2) & (3) & (4) & (5) & (6) & (7) & (8) \\
\hline & \multicolumn{2}{|c|}{ Net Affect } & \multicolumn{2}{|c|}{ u-index } & \multicolumn{2}{|c|}{ Net Affect } & \multicolumn{2}{|c|}{ u-index } \\
\hline & OLS & RE & OLS & RE & OLS & $\mathbf{R E}$ & OLS & $\mathbf{R E}$ \\
\hline Volunteering in diary & $\begin{array}{c}0.198^{* * * *} \\
(0.049)\end{array}$ & $\begin{array}{c}0.285^{* * *} \\
(0.066)\end{array}$ & $\begin{array}{c}-0.029 * * * \\
(0.009)\end{array}$ & $\begin{array}{c}-0.035^{* * *} \\
(0.011)\end{array}$ & $\begin{array}{c}0.144^{* * *} \\
(0.052)\end{array}$ & $\begin{array}{c}0.248^{* * *} \\
(0.067)\end{array}$ & $\begin{array}{c}-0.025^{* * *} \\
(0.010)\end{array}$ & $\begin{array}{c}-0.031^{* * *} \\
(0.011)\end{array}$ \\
\hline Male & $\begin{array}{c}0.196 * * * \\
(0.030)\end{array}$ & $\begin{array}{c}0.089 * * \\
(0.045)\end{array}$ & $\begin{array}{c}-0.061 * * * \\
(0.006)\end{array}$ & $\begin{array}{c}-0.040 * * * \\
(0.007)\end{array}$ & $\begin{array}{c}0.203 * * * \\
(0.030)\end{array}$ & $\begin{array}{c}0.090 * * \\
(0.045)\end{array}$ & $\begin{array}{c}-0.061 * * * \\
(0.006)\end{array}$ & $\begin{array}{c}-0.041 * * * \\
(0.007)\end{array}$ \\
\hline Age & $\begin{array}{c}-0.088 * * * \\
(0.009)\end{array}$ & $\begin{array}{c}-0.064 * * * \\
(0.015)\end{array}$ & $\begin{array}{c}0.017 * * * \\
(0.002)\end{array}$ & $\begin{array}{c}0.008 * * * \\
(0.002)\end{array}$ & $\begin{array}{c}-0.090 * * * \\
(0.010)\end{array}$ & $\begin{array}{c}-0.065^{* * * *} \\
(0.015)\end{array}$ & $\begin{array}{c}0.016^{* * *} \\
(0.002)\end{array}$ & $\begin{array}{c}0.008 * * * \\
(0.002)\end{array}$ \\
\hline Age squared & $\begin{array}{c}0.101 * * * \\
(0.011)\end{array}$ & $\begin{array}{c}0.069 * * * \\
(0.018)\end{array}$ & $\begin{array}{c}-0.020^{* * *} \\
(0.002)\end{array}$ & $\begin{array}{c}-0.009 * * * \\
(0.003)\end{array}$ & $\begin{array}{c}0.103^{* * *} * \\
(0.011)\end{array}$ & $\begin{array}{c}0.070 * * * \\
(0.018)\end{array}$ & $\begin{array}{c}-0.019 * * * \\
(0.002)\end{array}$ & $\begin{array}{c}-0.009 * * * \\
(0.003)\end{array}$ \\
\hline University education & $\begin{array}{c}0.113^{* *} \\
(0.054)\end{array}$ & $\begin{array}{l}-0.090 \\
(0.083)\end{array}$ & $\begin{array}{l}-0.007 \\
(0.010)\end{array}$ & $\begin{array}{c}0.015 \\
(0.014)\end{array}$ & $\begin{array}{c}0.143^{* * *} \\
(0.055)\end{array}$ & $\begin{array}{l}-0.086 \\
(0.083)\end{array}$ & $\begin{array}{l}-0.012 \\
(0.010)\end{array}$ & $\begin{array}{c}0.014 \\
(0.014)\end{array}$ \\
\hline Secondary education & $\begin{array}{c}0.171 * * * \\
(0.054)\end{array}$ & $\begin{array}{c}0.015 \\
(0.085)\end{array}$ & $\begin{array}{l}-0.011 \\
(0.010)\end{array}$ & $\begin{array}{c}0.006 \\
(0.014)\end{array}$ & $\begin{array}{c}0.208 * * * \\
(0.055)\end{array}$ & $\begin{array}{c}0.014 \\
(0.085)\end{array}$ & $\begin{array}{l}-0.016 \\
(0.010)\end{array}$ & $\begin{array}{c}0.006 \\
(0.014)\end{array}$ \\
\hline Working full-time & $\begin{array}{c}0.509 * * * \\
(0.039)\end{array}$ & $\begin{array}{c}0.487 * * * \\
(0.056)\end{array}$ & $\begin{array}{c}-0.050 * * * \\
(0.007)\end{array}$ & $\begin{array}{c}-0.060^{* * *} \\
(0.009)\end{array}$ & $\begin{array}{c}0.527 * * * \\
(0.039)\end{array}$ & $\begin{array}{c}0.494^{* * *} \\
(0.056)\end{array}$ & $\begin{array}{c}-0.050 * * * \\
(0.007)\end{array}$ & $\begin{array}{c}-0.061^{* * *} \\
(0.009)\end{array}$ \\
\hline Working part-time & $\begin{array}{c}0.533 * * * \\
(0.047)\end{array}$ & $\begin{array}{c}0.512 * * * \\
(0.068)\end{array}$ & $\begin{array}{c}-0.072 * * * \\
(0.009)\end{array}$ & $\begin{array}{c}-0.079 * * * \\
(0.011)\end{array}$ & $\begin{array}{c}0.555 * * * \\
(0.048)\end{array}$ & $\begin{array}{c}0.515^{* * *} \\
(0.068)\end{array}$ & $\begin{array}{c}-0.075^{* * *} \\
(0.009)\end{array}$ & $\begin{array}{c}-0.081 * * * \\
(0.011)\end{array}$ \\
\hline Number children $<18$ & $\begin{array}{c}0.052 \\
(0.037)\end{array}$ & $\begin{array}{l}-0.071 \\
(0.057)\end{array}$ & $\begin{array}{c}-0.019 * * * \\
(0.007)\end{array}$ & $\begin{array}{c}0.020 * * \\
(0.009)\end{array}$ & $\begin{array}{l}0.069 * \\
(0.037)\end{array}$ & $\begin{array}{c}-0.073 \\
(0.057)\end{array}$ & $\begin{array}{c}-0.020 * * * \\
(0.007)\end{array}$ & $\begin{array}{c}0.020^{* *} \\
(0.009)\end{array}$ \\
\hline Married & $\begin{array}{c}0.080^{* *} \\
(0.037)\end{array}$ & $\begin{array}{c}0.251 * * * \\
(0.055)\end{array}$ & $\begin{array}{c}-0.021 * * * \\
(0.007)\end{array}$ & $\begin{array}{c}-0.040^{* * * *} \\
(0.009)\end{array}$ & $\begin{array}{l}0.070^{*} \\
(0.038)\end{array}$ & $\begin{array}{c}0.255^{* * *} \\
(0.055)\end{array}$ & $\begin{array}{c}-0.024 * * * \\
(0.007)\end{array}$ & $\begin{array}{c}-0.042 * * * \\
(0.009)\end{array}$ \\
\hline Household Income & $\begin{array}{c}0.107 * * * \\
(0.019)\end{array}$ & $\begin{array}{c}0.134 * * * \\
(0.027)\end{array}$ & $\begin{array}{c}-0.013 * * * \\
(0.004)\end{array}$ & $\begin{array}{c}-0.020 * * * \\
(0.004)\end{array}$ & $\begin{array}{c}0.120 * * * \\
(0.019)\end{array}$ & $\begin{array}{c}0.133 * * * \\
(0.027)\end{array}$ & $\begin{array}{c}-0.014 * * * \\
(0.004)\end{array}$ & $\begin{array}{c}-0.020 * * * \\
(0.005)\end{array}$ \\
\hline Presence of child & $\begin{array}{c}0.719 * * * \\
(0.058)\end{array}$ & $\begin{array}{c}0.423 * * * \\
(0.035)\end{array}$ & $\begin{array}{c}-0.086^{* * *} \\
(0.011)\end{array}$ & $\begin{array}{c}-0.064 * * * \\
(0.007)\end{array}$ & $\begin{array}{c}0.729 * * * \\
(0.059)\end{array}$ & $\begin{array}{c}0.431^{* * * *} \\
(0.036)\end{array}$ & $\begin{array}{c}-0.086^{* * *} \\
(0.011)\end{array}$ & $\begin{array}{c}-0.066^{* * * *} \\
(0.008)\end{array}$ \\
\hline Presence of spouse/partner & $\begin{array}{c}0.378 * * * \\
(0.054)\end{array}$ & $\begin{array}{c}0.328 * * * \\
(0.036)\end{array}$ & $\begin{array}{c}-0.033^{* * *} \\
(0.010)\end{array}$ & $\begin{array}{c}-0.030 * * * \\
(0.008)\end{array}$ & $\begin{array}{c}0.380 * * * \\
(0.055)\end{array}$ & $\begin{array}{c}0.326 * * * \\
(0.036)\end{array}$ & $\begin{array}{c}-0.031 * * * \\
(0.010)\end{array}$ & $\begin{array}{c}-0.029 * * * \\
(0.008)\end{array}$ \\
\hline Presence of hhld. Adult & $\begin{array}{l}0.221^{*} \\
(0.131)\end{array}$ & $\begin{array}{l}0.173^{*} \\
(0.105)\end{array}$ & $\begin{array}{c}0.027 \\
(0.025)\end{array}$ & $\begin{array}{l}-0.015 \\
(0.022)\end{array}$ & $\begin{array}{l}0.256^{*} \\
(0.133)\end{array}$ & $\begin{array}{l}0.207^{*} \\
(0.106)\end{array}$ & $\begin{array}{c}0.022 \\
(0.025)\end{array}$ & $\begin{array}{l}-0.019 \\
(0.022)\end{array}$ \\
\hline Presence of friend(s) & $\begin{array}{c}0.582 * * * \\
(0.059)\end{array}$ & $\begin{array}{c}0.533^{* * *} \\
(0.039)\end{array}$ & $\begin{array}{c}-0.049 * * * \\
(0.011)\end{array}$ & $\begin{array}{c}-0.065^{* * *} \\
(0.008)\end{array}$ & $\begin{array}{c}0.550 * * * \\
(0.059)\end{array}$ & $\begin{array}{c}0.541^{* * *} \\
(0.040)\end{array}$ & $\begin{array}{c}-0.047 * * * \\
(0.011)\end{array}$ & $\begin{array}{c}-0.066 * * * \\
(0.008)\end{array}$ \\
\hline Presence of co-workers & $\begin{array}{c}-0.303^{* * *} \\
(0.060)\end{array}$ & $\begin{array}{c}-0.272 * * * \\
(0.048)\end{array}$ & $\begin{array}{c}0.076 * * * \\
(0.011)\end{array}$ & $\begin{array}{c}0.032 * * * \\
(0.010)\end{array}$ & $\begin{array}{c}-0.307 * * * \\
(0.060)\end{array}$ & $\begin{array}{c}-0.271 * * * \\
(0.048)\end{array}$ & $\begin{array}{c}0.073 * * * \\
(0.011)\end{array}$ & $\begin{array}{c}0.032 * * * \\
(0.010)\end{array}$ \\
\hline Total time with child & $\begin{array}{c}-0.045^{* * *} \\
(0.014)\end{array}$ & $\begin{array}{c}0.010 \\
(0.018)\end{array}$ & $\begin{array}{c}0.005^{* *} \\
(0.003)\end{array}$ & $\begin{array}{c}0.000 \\
(0.003)\end{array}$ & $\begin{array}{c}-0.047 * * * \\
(0.014)\end{array}$ & $\begin{array}{c}0.006 \\
(0.018)\end{array}$ & $\begin{array}{l}0.005^{*} \\
(0.003)\end{array}$ & $\begin{array}{c}0.000 \\
(0.003)\end{array}$ \\
\hline Total time with spouse/partner & $\begin{array}{c}0.009 \\
(0.013)\end{array}$ & $\begin{array}{l}-0.003 \\
(0.018)\end{array}$ & $\begin{array}{c}-0.001 \\
(0.002)\end{array}$ & $\begin{array}{c}0.000 \\
(0.003)\end{array}$ & $\begin{array}{c}0.010 \\
(0.013)\end{array}$ & $\begin{array}{c}0.000 \\
(0.018)\end{array}$ & $\begin{array}{c}0.000 \\
(0.002)\end{array}$ & $\begin{array}{c}0.000 \\
(0.003)\end{array}$ \\
\hline Total time with hhld. Adult & $\begin{array}{l}-0.008 \\
(0.031)\end{array}$ & $\begin{array}{l}-0.020 \\
(0.043)\end{array}$ & $\begin{array}{l}-0.008 \\
(0.006)\end{array}$ & $\begin{array}{c}0.001 \\
(0.007)\end{array}$ & $\begin{array}{c}-0.013 \\
(0.031)\end{array}$ & $\begin{array}{l}-0.037 \\
(0.045)\end{array}$ & $\begin{array}{l}-0.008 \\
(0.006)\end{array}$ & $\begin{array}{c}0.002 \\
(0.008)\end{array}$ \\
\hline Total time with friend(s) & $\begin{array}{c}-0.026 * * * \\
(0.008)\end{array}$ & $\begin{array}{l}-0.013 \\
(0.012)\end{array}$ & $\begin{array}{c}0.000 \\
(0.002)\end{array}$ & $\begin{array}{c}0.005^{* *} \\
(0.002)\end{array}$ & $\begin{array}{c}-0.026 * * * \\
(0.008)\end{array}$ & $\begin{array}{c}-0.014 \\
(0.012)\end{array}$ & $\begin{array}{c}0.000 \\
(0.002)\end{array}$ & $\begin{array}{c}0.005^{* *} \\
(0.002)\end{array}$ \\
\hline Total time with co-workers & $\begin{array}{c}0.014 \\
(0.012)\end{array}$ & $\begin{array}{l}0.026^{*} \\
(0.016)\end{array}$ & $\begin{array}{l}-0.004^{*} \\
(0.002)\end{array}$ & $\begin{array}{l}-0.003 \\
(0.003)\end{array}$ & $\begin{array}{l}0.021^{*} \\
(0.013)\end{array}$ & $\begin{array}{c}0.026 \\
(0.016)\end{array}$ & $\begin{array}{c}-0.006^{* * *} \\
(0.002)\end{array}$ & $\begin{array}{l}-0.003 \\
(0.003)\end{array}$ \\
\hline Constant & $\begin{array}{c}2.483 * * * \\
(0.300)\end{array}$ & $\begin{array}{c}2.183^{* * *} \\
(0.401)\end{array}$ & $\begin{array}{c}0.234^{* * *} \\
(0.056)\end{array}$ & $\begin{array}{c}0.348 * * * \\
(0.066)\end{array}$ & $\begin{array}{c}2.314 * * * \\
(0.302)\end{array}$ & $\begin{array}{c}2.197 * * * \\
(0.402)\end{array}$ & $\begin{array}{c}0.144^{* * *} \\
(0.050)\end{array}$ & $\begin{array}{c}0.350 * * * \\
(0.066)\end{array}$ \\
\hline Volunteering episodes in sample & Yes & Yes & Yes & Yes & No & No & No & No \\
\hline $\begin{array}{l}\text { Observations } \\
\text { R-squared }\end{array}$ & $\begin{array}{c}25,601 \\
0.060 \\
\end{array}$ & $\begin{array}{c}25,601 \\
0.054 \\
\end{array}$ & $\begin{array}{c}25,601 \\
0.034 \\
\end{array}$ & $\begin{array}{c}25,601 \\
0.032 \\
\end{array}$ & $\begin{array}{c}25,143 \\
0.061 \\
\end{array}$ & $\begin{array}{c}25,143 \\
0.054 \\
\end{array}$ & $\begin{array}{c}25,143 \\
0.034 \\
\end{array}$ & $\begin{array}{c}25,143 \\
0.033 \\
\end{array}$ \\
\hline
\end{tabular}

Note: Sample consists of non-retired/non-students respondents between 21-65 years old from the ATUS 2010 Well-being Module. Robust standard errors in parentheses. Columns (1) and (3) refer to OLS models for the net-affect and u-index respectively, considering all the activities. Columns (2) and (4) refer to RE models for the net-affect and u-index respectively, considering all the activities. Columns (5) and (7) refer to OLS models for the net-affect and u-index respectively, excluding episodes of voluntary activities. Columns (6) and (8) refer to RE models for the net-affect and u-index respectively, excluding episodes of voluntary activities. We also include day-of-week dummies in all of the regressions (ref.: Friday), variable dummies to control for residence in the Northeast, Midwest and South (ref.: West.), and the time of the day (e.g., time band) and its square * Significant at the $10 \%$ level $* *$ Significant at the $5 \%$ level *** Significant at the $1 \%$ level. 
Table 4. Results for time in voluntary activities

\begin{tabular}{|c|c|c|c|c|c|c|c|c|}
\hline & (1) & $\overline{(2)}$ & (3) & (4) & (5) & (6) & (7) & (8) \\
\hline & \multicolumn{2}{|c|}{ Net Affect } & \multicolumn{2}{|c|}{ u-index } & \multicolumn{2}{|c|}{ Net Affect } & \multicolumn{2}{|c|}{ u-index } \\
\hline & OLS & RE & OLS & RE & OLS & RE & OLS & RE \\
\hline Time in voluntary & $\begin{array}{c}0.057 * * * \\
(0.018)\end{array}$ & $\begin{array}{c}0.067 * * * \\
(0.024)\end{array}$ & $\begin{array}{l}-0.002 \\
(0.008)\end{array}$ & $\begin{array}{l}-0.006 \\
(0.004)\end{array}$ & $\begin{array}{l}0.045^{*} \\
(0.026)\end{array}$ & $\begin{array}{c}0.036 \\
(0.027)\end{array}$ & $\begin{array}{l}-0.005 \\
(0.009)\end{array}$ & $\begin{array}{l}-0.002 \\
(0.005)\end{array}$ \\
\hline Male & $\begin{array}{c}0.191 * * * \\
(0.030)\end{array}$ & $\begin{array}{l}0.083^{*} \\
(0.045)\end{array}$ & $\begin{array}{c}-0.060 * * * \\
(0.015)\end{array}$ & $\begin{array}{c}-0.040 * * * \\
(0.007)\end{array}$ & $\begin{array}{c}0.200 * * * \\
(0.030)\end{array}$ & $\begin{array}{l}0.086^{*} \\
(0.045)\end{array}$ & $\begin{array}{c}-0.061^{* * * *} \\
(0.015)\end{array}$ & $\begin{array}{c}-0.041 * * * \\
(0.007)\end{array}$ \\
\hline Age & $\begin{array}{c}-0.088^{* * *} \\
(0.009)\end{array}$ & $\begin{array}{c}-0.063^{* * *} \\
(0.015)\end{array}$ & $\begin{array}{c}0.016 * * * \\
(0.005)\end{array}$ & $\begin{array}{c}0.008 * * * \\
(0.002)\end{array}$ & $\begin{array}{c}-0.090 * * * \\
(0.010)\end{array}$ & $\begin{array}{c}-0.064 * * * \\
(0.015)\end{array}$ & $\begin{array}{c}0.016^{* * *} \\
(0.005)\end{array}$ & $\begin{array}{c}0.008 * * * \\
(0.002)\end{array}$ \\
\hline Age squared & $\begin{array}{c}0.101 * * * \\
(0.011)\end{array}$ & $\begin{array}{c}0.068 * * * \\
(0.018)\end{array}$ & $\begin{array}{c}-0.019 * * * \\
(0.006)\end{array}$ & $\begin{array}{c}-0.009 * * * \\
(0.003)\end{array}$ & $\begin{array}{c}0.103 * * * \\
(0.011)\end{array}$ & $\begin{array}{c}0.069 * * * \\
(0.018)\end{array}$ & $\begin{array}{c}-0.019 * * * \\
(0.006)\end{array}$ & $\begin{array}{c}-0.009 * * * \\
(0.003)\end{array}$ \\
\hline University education & $\begin{array}{c}0.112^{* *} \\
(0.054)\end{array}$ & $\begin{array}{l}-0.088 \\
(0.083)\end{array}$ & $\begin{array}{l}-0.007 \\
(0.027)\end{array}$ & $\begin{array}{c}0.015 \\
(0.014)\end{array}$ & $\begin{array}{c}0.144^{* * *} \\
(0.055)\end{array}$ & $\begin{array}{l}-0.081 \\
(0.083)\end{array}$ & $\begin{array}{l}-0.011 \\
(0.026)\end{array}$ & $\begin{array}{c}0.014 \\
(0.014)\end{array}$ \\
\hline Secondary education & $\begin{array}{c}0.171^{* * *} \\
(0.054)\end{array}$ & $\begin{array}{c}0.012 \\
(0.085)\end{array}$ & $\begin{array}{c}-0.011 \\
(0.027)\end{array}$ & $\begin{array}{c}0.007 \\
(0.014)\end{array}$ & $\begin{array}{c}0.208^{* * *} \\
(0.055)\end{array}$ & $\begin{array}{c}0.013 \\
(0.085)\end{array}$ & $\begin{array}{l}-0.015 \\
(0.027)\end{array}$ & $\begin{array}{c}0.006 \\
(0.014)\end{array}$ \\
\hline Working full-time & $\begin{array}{c}0.515^{* * *} \\
(0.039)\end{array}$ & $\begin{array}{c}0.496 * * * \\
(0.056)\end{array}$ & $\begin{array}{c}-0.050 * * * \\
(0.018)\end{array}$ & $\begin{array}{c}-0.063^{* * *} \\
(0.009)\end{array}$ & $\begin{array}{c}0.529 * * * \\
(0.039)\end{array}$ & $\begin{array}{c}0.500 * * * \\
(0.056)\end{array}$ & $\begin{array}{c}-0.051^{* * *} \\
(0.018)\end{array}$ & $\begin{array}{c}-0.063 * * * \\
(0.009)\end{array}$ \\
\hline Working part-time & $\begin{array}{c}0.538 * * * \\
(0.047)\end{array}$ & $\begin{array}{c}0.515^{* * *} \\
(0.068)\end{array}$ & $\begin{array}{c}-0.073 * * * \\
(0.022)\end{array}$ & $\begin{array}{c}-0.080 * * * \\
(0.011)\end{array}$ & $\begin{array}{c}0.558 * * * \\
(0.048)\end{array}$ & $\begin{array}{c}0.518 * * * \\
(0.068)\end{array}$ & $\begin{array}{c}-0.075^{* * * *} \\
(0.023)\end{array}$ & $\begin{array}{c}-0.082 * * * \\
(0.011)\end{array}$ \\
\hline Number children $<18$ & $\begin{array}{c}0.051 \\
(0.037)\end{array}$ & $\begin{array}{l}-0.066 \\
(0.057)\end{array}$ & $\begin{array}{l}-0.020 \\
(0.019)\end{array}$ & $\begin{array}{c}0.019 * * \\
(0.009)\end{array}$ & $\begin{array}{l}0.069^{*} \\
(0.037)\end{array}$ & $\begin{array}{l}-0.067 \\
(0.057)\end{array}$ & $\begin{array}{l}-0.021 \\
(0.019)\end{array}$ & $\begin{array}{c}0.019 * * \\
(0.009)\end{array}$ \\
\hline Married & $\begin{array}{c}0.081^{* *} \\
(0.037)\end{array}$ & $\begin{array}{c}0.253^{* * *} \\
(0.055)\end{array}$ & $\begin{array}{l}-0.022 \\
(0.019)\end{array}$ & $\begin{array}{c}-0.040 * * * \\
(0.009)\end{array}$ & $\begin{array}{l}0.071^{*} \\
(0.038)\end{array}$ & $\begin{array}{c}0.258 * * * \\
(0.055)\end{array}$ & $\begin{array}{l}-0.023 \\
(0.019)\end{array}$ & $\begin{array}{c}-0.042 * * * \\
(0.009)\end{array}$ \\
\hline Household Income & $\begin{array}{c}0.107 * * * \\
(0.019)\end{array}$ & $\begin{array}{c}0.134 * * * \\
(0.027)\end{array}$ & $\begin{array}{l}-0.014 \\
(0.009)\end{array}$ & $\begin{array}{c}-0.020 * * * \\
(0.004)\end{array}$ & $\begin{array}{c}0.120^{* * *} \\
(0.019)\end{array}$ & $\begin{array}{c}0.134 * * * \\
(0.027)\end{array}$ & $\begin{array}{l}-0.015 \\
(0.009)\end{array}$ & $\begin{array}{c}-0.020 * * * \\
(0.004)\end{array}$ \\
\hline Presence of child & $\begin{array}{c}0.721 * * * \\
(0.058)\end{array}$ & $\begin{array}{c}0.421 * * * \\
(0.035)\end{array}$ & $\begin{array}{c}-0.086^{* * *} \\
(0.018)\end{array}$ & $\begin{array}{c}-0.063 * * * \\
(0.007)\end{array}$ & $\begin{array}{c}0.729 * * * \\
(0.059)\end{array}$ & $\begin{array}{c}0.429 * * * \\
(0.036)\end{array}$ & $\begin{array}{c}-0.085^{* * * *} \\
(0.018)\end{array}$ & $\begin{array}{c}-0.065^{* * *} \\
(0.008)\end{array}$ \\
\hline Presence of spouse/partner & $\begin{array}{c}0.380 * * * \\
(0.054)\end{array}$ & $\begin{array}{c}0.333 * * * \\
(0.036)\end{array}$ & $\begin{array}{c}-0.033^{*} \\
(0.018)\end{array}$ & $\begin{array}{c}-0.031^{* * *} \\
(0.008)\end{array}$ & $\begin{array}{c}0.381^{* * *} \\
(0.055)\end{array}$ & $\begin{array}{c}0.331 * * * \\
(0.036)\end{array}$ & $\begin{array}{l}-0.033^{*} \\
(0.018)\end{array}$ & $\begin{array}{c}-0.030 \text { *** } \\
(0.008)\end{array}$ \\
\hline Presence of hhld. Adult & $\begin{array}{l}0.219 * \\
(0.131)\end{array}$ & $\begin{array}{c}0.169 \\
(0.105)\end{array}$ & $\begin{array}{c}0.028 \\
(0.042)\end{array}$ & $\begin{array}{l}-0.013 \\
(0.022)\end{array}$ & $\begin{array}{l}0.251^{*} \\
(0.133)\end{array}$ & $\begin{array}{l}0.201^{*} \\
(0.106)\end{array}$ & $\begin{array}{c}0.025 \\
(0.043)\end{array}$ & $\begin{array}{l}-0.017 \\
(0.022)\end{array}$ \\
\hline Presence of friend(s) & $\begin{array}{c}0.589 * * * \\
(0.058)\end{array}$ & $\begin{array}{c}0.525 * * * \\
(0.039)\end{array}$ & $\begin{array}{c}-0.051^{* * *} \\
(0.019)\end{array}$ & $\begin{array}{c}-0.062 * * * \\
(0.008)\end{array}$ & $\begin{array}{c}0.556^{* * *} \\
(0.059)\end{array}$ & $\begin{array}{c}0.534 * * * \\
(0.040)\end{array}$ & $\begin{array}{c}-0.047^{* *} \\
(0.020)\end{array}$ & $\begin{array}{c}-0.063 * * * \\
(0.008)\end{array}$ \\
\hline Presence of co-workers & $\begin{array}{c}-0.310^{* * *} \\
(0.060)\end{array}$ & $\begin{array}{c}-0.303^{* * * *} \\
(0.048)\end{array}$ & $\begin{array}{c}0.076 * * * \\
(0.026)\end{array}$ & $\begin{array}{c}0.043^{* * *} \\
(0.010)\end{array}$ & $\begin{array}{c}-0.310 * * * \\
(0.060)\end{array}$ & $\begin{array}{c}-0.302^{* * *} \\
(0.049)\end{array}$ & $\begin{array}{c}0.077 * * * \\
(0.026)\end{array}$ & $\begin{array}{c}0.043 * * * \\
(0.011)\end{array}$ \\
\hline Total time with child & $\begin{array}{c}-0.045^{* * *} \\
(0.014)\end{array}$ & $\begin{array}{c}0.008 \\
(0.018)\end{array}$ & $\begin{array}{c}0.005 \\
(0.007)\end{array}$ & $\begin{array}{c}0.000 \\
(0.003)\end{array}$ & $\begin{array}{c}-0.047 * * * \\
(0.014)\end{array}$ & $\begin{array}{c}0.005 \\
(0.018)\end{array}$ & $\begin{array}{c}0.005 \\
(0.007)\end{array}$ & $\begin{array}{c}0.001 \\
(0.003)\end{array}$ \\
\hline Total time with spouse/partner & $\begin{array}{c}0.009 \\
(0.013)\end{array}$ & $\begin{array}{l}-0.004 \\
(0.018)\end{array}$ & $\begin{array}{l}-0.001 \\
(0.005)\end{array}$ & $\begin{array}{c}0.001 \\
(0.003)\end{array}$ & $\begin{array}{c}0.009 \\
(0.013)\end{array}$ & $\begin{array}{l}-0.002 \\
(0.018)\end{array}$ & $\begin{array}{c}0.000 \\
(0.005)\end{array}$ & $\begin{array}{c}0.000 \\
(0.003)\end{array}$ \\
\hline Total time with hhld. Adult & $\begin{array}{l}-0.008 \\
(0.031)\end{array}$ & $\begin{array}{l}-0.021 \\
(0.043)\end{array}$ & $\begin{array}{l}-0.008 \\
(0.011)\end{array}$ & $\begin{array}{c}0.000 \\
(0.007)\end{array}$ & $\begin{array}{l}-0.010 \\
(0.031)\end{array}$ & $\begin{array}{l}-0.035 \\
(0.045)\end{array}$ & $\begin{array}{l}-0.009 \\
(0.012)\end{array}$ & $\begin{array}{c}0.002 \\
(0.008)\end{array}$ \\
\hline Total time with friend(s) & $\begin{array}{c}-0.026 * * * \\
(0.008)\end{array}$ & $\begin{array}{l}-0.012 \\
(0.012)\end{array}$ & $\begin{array}{c}0.000 \\
(0.004)\end{array}$ & $\begin{array}{c}0.004 * * \\
(0.002)\end{array}$ & $\begin{array}{c}-0.026 * * * \\
(0.008)\end{array}$ & $\begin{array}{l}-0.013 \\
(0.012)\end{array}$ & $\begin{array}{c}0.000 \\
(0.004)\end{array}$ & $\begin{array}{c}0.004 * * \\
(0.002)\end{array}$ \\
\hline Total time with co-workers & $\begin{array}{c}0.013 \\
(0.012)\end{array}$ & $\begin{array}{l}0.027^{*} \\
(0.016)\end{array}$ & $\begin{array}{l}-0.004 \\
(0.005)\end{array}$ & $\begin{array}{l}-0.004 \\
(0.003)\end{array}$ & $\begin{array}{c}0.020 \\
(0.013)\end{array}$ & $\begin{array}{l}0.028^{*} \\
(0.016)\end{array}$ & $\begin{array}{l}-0.006 \\
(0.005)\end{array}$ & $\begin{array}{l}-0.004 \\
(0.003)\end{array}$ \\
\hline Constant & $\begin{array}{c}2.480 * * * \\
(0.300)\end{array}$ & $\begin{array}{c}1.693 * * * \\
(0.412)\end{array}$ & $\begin{array}{l}0.237^{*} \\
(0.138)\end{array}$ & $\begin{array}{c}0.520 * * * \\
(0.069)\end{array}$ & $\begin{array}{c}2.307^{* * * *} \\
(0.302)\end{array}$ & $\begin{array}{c}1.697 * * * \\
(0.413)\end{array}$ & $\begin{array}{l}0.256^{*} \\
(0.138)\end{array}$ & $\begin{array}{c}0.523^{* * *} \\
(0.069)\end{array}$ \\
\hline Volunt. episode in sample & Yes & Yes & Yes & Yes & No & No & No & No \\
\hline Observations & 25,601 & 25,601 & 25,601 & 25,601 & 25,143 & 25,143 & 25,143 & 25,143 \\
\hline$R$-squared & 0.059 & 0.054 & 0.034 & 0.035 & 0.061 & 0.054 & 0.034 & 0.035 \\
\hline
\end{tabular}

Note: Sample consists of non-retired/non-students respondents between 21-65 years old from the ATUS 2010 Well-being Module. Robust standard errors in parentheses. Columns (1) and (3) refer to OLS models for the net-affect and u-index respectively, considering all the activities. Columns (2) and (4) refer to RE models for the net-affect and u-index respectively, considering all the activities. Columns (5) and (7) refer to OLS models for the net-affect and u-index respectively, excluding episodes of voluntary activities. Columns (6) and (8) refer to RE models for the net-affect and u-index respectively, excluding episodes of voluntary activities. We also include day-of-week dummies in all of the regressions (ref.: Friday), variable dummies to control for residence in the Northeast, Midwest and South (ref.: West.), and the time of the day (e.g., time band) and its square * Significant at the $10 \%$ level ** Significant at the $5 \%$ level *** Significant at the $1 \%$ level. 
Table 5. Religiosity and participation in voluntary activities

\begin{tabular}{|c|c|c|c|c|c|c|c|c|}
\hline & (1) & $(2)$ & (3) & (4) & (5) & (6) & (7) & (8) \\
\hline & \multicolumn{2}{|c|}{ Net Affect } & \multicolumn{2}{|c|}{ u-index } & \multicolumn{2}{|c|}{ Net Affect } & \multicolumn{2}{|c|}{ u-index } \\
\hline & OLS & $\mathbf{R E}$ & OLS & $\mathbf{R E}$ & OLS & $\mathbf{R E}$ & OLS & $\mathbf{R E}$ \\
\hline & \multicolumn{8}{|c|}{ Panel A: Interaction between participation in voluntary activities and weekday/non-weekday } \\
\hline Participation in voluntary act. & $\begin{array}{l}0.207 * * * \\
(0.073)\end{array}$ & $\begin{array}{c}0.345^{* * *} \\
(0.080)\end{array}$ & $\begin{array}{l}-0.014 \\
(0.014)\end{array}$ & $\begin{array}{c}-0.039 * * * \\
(0.013)\end{array}$ & $\begin{array}{l}0.202 * * * \\
(0.076)\end{array}$ & $\begin{array}{c}0.310 * * * \\
(0.082)\end{array}$ & $\begin{array}{l}-0.017 \\
(0.014)\end{array}$ & $\begin{array}{c}-0.037 * * * \\
(0.014)\end{array}$ \\
\hline Weekday & $\begin{array}{c}-0.187 * * * \\
(0.036)\end{array}$ & $\begin{array}{c}-0.221 * * * \\
(0.047)\end{array}$ & $\begin{array}{c}0.027 * * * \\
(0.007)\end{array}$ & $\begin{array}{c}0.029 * * * \\
(0.008)\end{array}$ & $\begin{array}{c}-0.185^{* * *} \\
(0.036)\end{array}$ & $\begin{array}{c}-0.220 * * * \\
(0.047)\end{array}$ & $\begin{array}{c}0.027 * * * \\
(0.007)\end{array}$ & $\begin{array}{c}0.028^{* * *} \\
(0.008)\end{array}$ \\
\hline $\begin{array}{l}\text { Participation in voluntary } \\
\text { act.*Weekday }\end{array}$ & $\begin{array}{c}0.008 \\
(0.097)\end{array}$ & $\begin{array}{l}-0.188 \\
(0.136)\end{array}$ & $\begin{array}{l}-0.027 \\
(0.018)\end{array}$ & $\begin{array}{c}0.015 \\
(0.022)\end{array}$ & $\begin{array}{l}-0.081 \\
(0.103)\end{array}$ & $\begin{array}{l}-0.196 \\
(0.139)\end{array}$ & $\begin{array}{l}-0.016 \\
(0.019)\end{array}$ & $\begin{array}{c}0.021 \\
(0.023)\end{array}$ \\
\hline Volunt. episode in sample & Yes & Yes & Yes & Yes & No & No & No & No \\
\hline Observations & 25,601 & 25,601 & 25,601 & 25,601 & 25,143 & 25,143 & 25,143 & 25,143 \\
\hline \multirow[t]{2}{*}{$R$-squared } & 0.058 & 0.055 & 0.033 & 0.035 & 0.059 & 0.055 & 0.033 & 0.035 \\
\hline & \multicolumn{8}{|c|}{ Panel B: Inclusion of religious activities in definition of voluntary activities } \\
\hline $\begin{array}{l}\text { Participation in voluntary } \\
\text { act.including religious act. }\end{array}$ & $\begin{array}{c}0.571 * * * \\
(0.065)\end{array}$ & $\begin{array}{c}0.547^{* * *} \\
(0.087)\end{array}$ & $\begin{array}{c}-0.050 * * * \\
(0.012)\end{array}$ & $\begin{array}{c}-0.050 * * * \\
(0.014)\end{array}$ & $\begin{array}{c}0.560 * * * \\
(0.073)\end{array}$ & $\begin{array}{c}0.499 * * * \\
(0.091)\end{array}$ & $\begin{array}{c}-0.049 * * * \\
(0.014)\end{array}$ & $\begin{array}{c}-0.044 * * * \\
(0.015)\end{array}$ \\
\hline Volunt. episode in sample & Yes & Yes & Yes & Yes & No & No & No & No \\
\hline Observations & 25,601 & 25,601 & 25,601 & 25,601 & 25,143 & 25,143 & 25,143 & 25,143 \\
\hline \multirow{2}{*}{$R$-squared } & 0.058 & 0.033 & 0.055 & 0.035 & 0.059 & 0.033 & 0.055 & 0.035 \\
\hline & \multicolumn{8}{|c|}{ Panel C: Interaction between participation in voluntary activities and going to church } \\
\hline Participation in voluntary act. & $\begin{array}{c}0.079 \\
(0.053)\end{array}$ & $\begin{array}{c}0.189 * * * \\
(0.072)\end{array}$ & $\begin{array}{c}-0.024 * * \\
(0.010)\end{array}$ & $\begin{array}{c}-0.026^{* *} \\
(0.012)\end{array}$ & $\begin{array}{c}0.018 \\
(0.056)\end{array}$ & $\begin{array}{c}0.151^{* *} \\
(0.074)\end{array}$ & $\begin{array}{c}-0.020 * * \\
(0.010)\end{array}$ & $\begin{array}{l}-0.023^{*} \\
(0.012)\end{array}$ \\
\hline To church during the day & $\begin{array}{c}0.551 * * * \\
(0.212)\end{array}$ & $\begin{array}{c}0.441 \\
(0.350)\end{array}$ & $\begin{array}{c}-0.118^{* * *} \\
(0.040)\end{array}$ & $\begin{array}{l}-0.080 \\
(0.057)\end{array}$ & $\begin{array}{c}0.551 * * * \\
(0.213)\end{array}$ & $\begin{array}{c}0.439 \\
(0.350)\end{array}$ & $\begin{array}{c}-0.118 * * * \\
(0.040)\end{array}$ & $\begin{array}{l}-0.080 \\
(0.057)\end{array}$ \\
\hline $\begin{array}{l}\text { Participation in voluntary act. *To } \\
\text { church during the day }\end{array}$ & $\begin{array}{c}0.186 \\
(0.244)\end{array}$ & $\begin{array}{c}0.057 \\
(0.381)\end{array}$ & $\begin{array}{l}0.082 * \\
(0.046)\end{array}$ & $\begin{array}{c}0.034 \\
(0.062)\end{array}$ & $\begin{array}{c}0.242 \\
(0.249)\end{array}$ & $\begin{array}{c}0.070 \\
(0.382)\end{array}$ & $\begin{array}{l}0.082 * \\
(0.047)\end{array}$ & $\begin{array}{c}0.038 \\
(0.063)\end{array}$ \\
\hline Volunt. episode in sample & Yes & Yes & Yes & Yes & No & No & No & No \\
\hline Observations & 25,601 & 25,601 & 25,601 & 25,601 & 25,143 & 25,143 & 25,143 & 25,143 \\
\hline \multirow[t]{2}{*}{$R$-squared } & 0.061 & 0.056 & 0.035 & 0.036 & 0.062 & 0.056 & 0.035 & 0.036 \\
\hline & \multicolumn{8}{|c|}{ Panel D: Analysis for participation in voluntary activites in non-working days only } \\
\hline Participation in voluntary act. & $\begin{array}{c}0.25^{* * *} \\
(0.065)\end{array}$ & $\begin{array}{c}0.29 * * * \\
(0.089)\end{array}$ & $\begin{array}{l}-0.010 \\
(0.011)\end{array}$ & $\begin{array}{c}-0.03^{* *} \\
(0.013)\end{array}$ & $\begin{array}{c}0.20 * * * \\
(0.069)\end{array}$ & $\begin{array}{c}0.27 * * * \\
(0.090)\end{array}$ & $\begin{array}{l}-0.010 \\
(0.012)\end{array}$ & $\begin{array}{l}-0.03^{* *} \\
(0.014)\end{array}$ \\
\hline Volunt. episode in sample & Yes & Yes & Yes & Yes & No & No & No & No \\
\hline Observations & 12,928 & 12,928 & 12,928 & 12,928 & 12,612 & 12,612 & 12,612 & 12,612 \\
\hline$R$-squared & 0.082 & 0.075 & 0.056 & 0.037 & 0.084 & 0.075 & 0.058 & 0.033 \\
\hline
\end{tabular}

Note: Sample consists of non-retired/non-students respondents between 21-65 years old from the ATUS 2010 Well-being Module. Robust standard errors in parentheses. Columns (1) and (3) refer to OLS models for the net-affect and u-index respectively, considering all the activities. Columns (2) and (4) refer to RE models for the net-affect and u-index respectively, considering all the activities. Columns (5) and (7) refer to OLS models for the net-affect and u-index respectively, excluding episodes of voluntary activities. Columns (6) and (8) refer to RE models for the net-affect and u-index respectively, excluding episodes of voluntary activities. We also include day-of-week dummies in all of the regressions (ref.: Friday), variable dummies to control for residence in the Northeast, Midwest and South (ref.: West.), and the time of the day (e.g., time band) and its square * Significant at the $10 \%$ level $* *$ Significant at the $5 \%$ level *** Significant at the $1 \%$ level. 
Table 6. IV regression results, participation in voluntary activities

\begin{tabular}{|c|c|c|c|c|c|c|c|c|}
\hline & $(1)$ & $(2)$ & (3) & $(4)$ & (5) & $(6)$ & $(7)$ & $(8)$ \\
\hline & \multicolumn{2}{|c|}{ IV 2SLS } & \multicolumn{2}{|c|}{ G2SLS random-effects } & \multicolumn{2}{|c|}{ IV 2SLS } & \multicolumn{2}{|c|}{ GLS random-effects } \\
\hline & Net affect & u-index & Net affect & u-index & Net affect & u-index & Net affect & u-index \\
\hline Volunteering in diary & $\begin{array}{c}0.690 \\
(1.503)\end{array}$ & $\begin{array}{c}-0.421 \\
(0.290)\end{array}$ & $\begin{array}{c}-0.811 \\
(2.655)\end{array}$ & $\begin{array}{c}0.183 \\
(0.440)\end{array}$ & $\begin{array}{c}0.542 \\
(1.428)\end{array}$ & $\begin{array}{c}-0.530^{*} \\
(0.282)\end{array}$ & $\begin{array}{c}-0.105 \\
(2.064)\end{array}$ & $\begin{array}{c}0.029 \\
(0.339)\end{array}$ \\
\hline Male & $\begin{array}{c}0.214^{* * *} * \\
(0.062)\end{array}$ & $\begin{array}{c}-0.075 * * * \\
(0.012)\end{array}$ & $\begin{array}{c}0.058 \\
(0.092)\end{array}$ & $\begin{array}{c}-0.034 * * \\
(0.015)\end{array}$ & $\begin{array}{c}0.209 * * * \\
(0.060)\end{array}$ & $\begin{array}{c}-0.079 * * * \\
(0.012)\end{array}$ & $\begin{array}{c}0.079 \\
(0.076)\end{array}$ & $\begin{array}{c}-0.039 * * * \\
(0.012)\end{array}$ \\
\hline Age & $\begin{array}{c}-0.092 * * * \\
(0.014)\end{array}$ & $\begin{array}{c}0.019 * * * \\
(0.003)\end{array}$ & $\begin{array}{c}-0.057 * * \\
(0.024)\end{array}$ & $\begin{array}{l}0.007^{*} \\
(0.004)\end{array}$ & $\begin{array}{c}-0.091 * * * \\
(0.013)\end{array}$ & $\begin{array}{c}0.020 * * * \\
(0.003)\end{array}$ & $\begin{array}{c}-0.061 * * * \\
(0.021)\end{array}$ & $\begin{array}{c}0.008 * * \\
(0.003)\end{array}$ \\
\hline Age squared & $\begin{array}{c}0.104^{* * *} \\
(0.015)\end{array}$ & $\begin{array}{c}-0.022 * * * \\
(0.003)\end{array}$ & $\begin{array}{c}0.063 * * * \\
(0.023)\end{array}$ & $\begin{array}{c}-0.008^{* *} \\
(0.004)\end{array}$ & $\begin{array}{c}0.103^{* * *} \\
(0.015)\end{array}$ & $\begin{array}{c}-0.023 * * * \\
(0.003)\end{array}$ & $\begin{array}{c}0.067 * * * \\
(0.021)\end{array}$ & $\begin{array}{c}-0.009 * * * \\
(0.003)\end{array}$ \\
\hline University education & $\begin{array}{c}0.099 \\
(0.069)\end{array}$ & $\begin{array}{c}0.004 \\
(0.013)\end{array}$ & $\begin{array}{c}-0.037 \\
(0.158)\end{array}$ & $\begin{array}{c}0.005 \\
(0.026)\end{array}$ & $\begin{array}{c}0.103 \\
(0.068)\end{array}$ & $\begin{array}{c}0.008 \\
(0.013)\end{array}$ & $\begin{array}{c}-0.072 \\
(0.133)\end{array}$ & $\begin{array}{c}0.013 \\
(0.022)\end{array}$ \\
\hline Secondary education & $\begin{array}{c}0.171^{* * *} \\
(0.054)\end{array}$ & $\begin{array}{l}-0.010 \\
(0.011)\end{array}$ & $\begin{array}{c}0.028 \\
(0.094)\end{array}$ & $\begin{array}{c}0.004 \\
(0.015)\end{array}$ & $\begin{array}{c}0.171^{* * *} \\
(0.054)\end{array}$ & $\begin{array}{l}-0.010 \\
(0.011)\end{array}$ & $\begin{array}{c}0.018 \\
(0.090)\end{array}$ & $\begin{array}{c}0.006 \\
(0.015)\end{array}$ \\
\hline Working full-time & $\begin{array}{c}0.512 * * * \\
(0.040)\end{array}$ & $\begin{array}{c}-0.052 * * * \\
(0.008)\end{array}$ & $\begin{array}{c}0.478 * * * \\
(0.070)\end{array}$ & $\begin{array}{c}-0.060 * * * \\
(0.011)\end{array}$ & $\begin{array}{c}0.511 * * * \\
(0.040)\end{array}$ & $\begin{array}{c}-0.052 * * * \\
(0.008)\end{array}$ & $\begin{array}{c}0.489 * * * \\
(0.064)\end{array}$ & $\begin{array}{c}-0.062 * * * \\
(0.010)\end{array}$ \\
\hline Working part-time & $\begin{array}{c}0.527 * * * \\
(0.051)\end{array}$ & $\begin{array}{c}-0.067 * * * \\
(0.010)\end{array}$ & $\begin{array}{c}0.513^{* * *} \\
(0.068)\end{array}$ & $\begin{array}{c}-0.080 * * * \\
(0.011)\end{array}$ & $\begin{array}{c}0.529 * * * \\
(0.051)\end{array}$ & $\begin{array}{c}-0.066 * * * \\
(0.010)\end{array}$ & $\begin{array}{c}0.514^{* * *} \\
(0.067)\end{array}$ & $\begin{array}{c}-0.080 * * * \\
(0.011)\end{array}$ \\
\hline Number children $<18$ & $\begin{array}{c}0.043 \\
(0.047)\end{array}$ & $\begin{array}{c}-0.012 \\
(0.009)\end{array}$ & $\begin{array}{l}-0.042 \\
(0.087)\end{array}$ & $\begin{array}{c}0.014 \\
(0.014)\end{array}$ & $\begin{array}{c}0.045 \\
(0.046)\end{array}$ & $\begin{array}{l}-0.010 \\
(0.009)\end{array}$ & $\begin{array}{c}-0.060 \\
(0.076)\end{array}$ & $\begin{array}{c}0.018 \\
(0.012)\end{array}$ \\
\hline Married & $\begin{array}{c}0.069 \\
(0.049)\end{array}$ & $\begin{array}{l}-0.013 \\
(0.009)\end{array}$ & $\begin{array}{c}0.282 * * * \\
(0.098)\end{array}$ & $\begin{array}{c}-0.046^{* * *} \\
(0.016)\end{array}$ & $\begin{array}{c}0.072 \\
(0.048)\end{array}$ & $\begin{array}{l}-0.011 \\
(0.009)\end{array}$ & $\begin{array}{c}0.260 * * * \\
(0.083)\end{array}$ & $\begin{array}{c}-0.041^{* * *} \\
(0.013)\end{array}$ \\
\hline Household Income & $\begin{array}{c}0.106^{* * *} \\
(0.019)\end{array}$ & $\begin{array}{c}-0.012^{* * *} \\
(0.004)\end{array}$ & $\begin{array}{c}0.135^{* * *} \\
(0.028)\end{array}$ & $\begin{array}{c}-0.020 * * * \\
(0.005)\end{array}$ & $\begin{array}{c}0.106^{* * *} \\
(0.019)\end{array}$ & $\begin{array}{c}-0.012 * * * \\
(0.004)\end{array}$ & $\begin{array}{c}0.134^{* * *} \\
(0.028)\end{array}$ & $\begin{array}{c}-0.020^{* * *} \\
(0.005)\end{array}$ \\
\hline Presence of child & $\begin{array}{c}0.722^{* * *} \\
(0.059)\end{array}$ & $\begin{array}{c}-0.088^{* * *} \\
(0.011)\end{array}$ & $\begin{array}{c}0.427 * * * \\
(0.041)\end{array}$ & $\begin{array}{c}-0.065^{* * *} \\
(0.009)\end{array}$ & $\begin{array}{c}0.721^{* * *} \\
(0.059)\end{array}$ & $\begin{array}{c}-0.089 * * * \\
(0.012)\end{array}$ & $\begin{array}{c}0.423^{* * *} \\
(0.039)\end{array}$ & $\begin{array}{c}-0.064^{* * *} \\
(0.009)\end{array}$ \\
\hline Presence of spouse/partner & $\begin{array}{c}0.367 * * * \\
(0.064)\end{array}$ & $\begin{array}{c}-0.024^{* *} \\
(0.012)\end{array}$ & $\begin{array}{c}0.338 * * * \\
(0.039)\end{array}$ & $\begin{array}{c}-0.033^{* * *} \\
(0.009)\end{array}$ & $\begin{array}{c}0.371 * * * \\
(0.063)\end{array}$ & $\begin{array}{c}-0.022^{*} \\
(0.012)\end{array}$ & $\begin{array}{c}0.334 * * * \\
(0.038)\end{array}$ & $\begin{array}{c}-0.032 * * * \\
(0.008)\end{array}$ \\
\hline Presence of hhld. Adult & $\begin{array}{c}0.244 \\
(0.149)\end{array}$ & $\begin{array}{c}0.009 \\
(0.029)\end{array}$ & $\begin{array}{c}0.163 \\
(0.106)\end{array}$ & $\begin{array}{l}-0.011 \\
(0.022)\end{array}$ & $\begin{array}{c}0.237 \\
(0.147)\end{array}$ & $\begin{array}{c}0.004 \\
(0.029)\end{array}$ & $\begin{array}{c}0.166 \\
(0.106)\end{array}$ & $\begin{array}{l}-0.013 \\
(0.022)\end{array}$ \\
\hline Presence of friend(s) & $\begin{array}{c}0.553^{* * *} \\
(0.107)\end{array}$ & $\begin{array}{c}-0.026 \\
(0.021)\end{array}$ & $\begin{array}{c}0.535^{* * *} \\
(0.048)\end{array}$ & $\begin{array}{c}-0.066 * * * \\
(0.011)\end{array}$ & $\begin{array}{c}0.562 * * * \\
(0.103)\end{array}$ & $\begin{array}{l}-0.019 \\
(0.020)\end{array}$ & $\begin{array}{c}0.528 * * * \\
(0.045)\end{array}$ & $\begin{array}{c}-0.063^{* * *} \\
(0.010)\end{array}$ \\
\hline Presence of co-workers & $\begin{array}{c}-0.295 * * * \\
(0.065)\end{array}$ & $\begin{array}{c}0.069 * * * \\
(0.013)\end{array}$ & $\begin{array}{c}-0.303^{* * * *} \\
(0.049)\end{array}$ & $\begin{array}{c}0.043^{* * *} \\
(0.011)\end{array}$ & $\begin{array}{c}-0.297 * * * \\
(0.064)\end{array}$ & $\begin{array}{c}0.067 * * * \\
(0.013)\end{array}$ & $\begin{array}{c}-0.302 * * * \\
(0.048)\end{array}$ & $\begin{array}{c}0.043 * * * \\
(0.011)\end{array}$ \\
\hline Total time with child & $\begin{array}{c}-0.045^{* * *} \\
(0.014)\end{array}$ & $\begin{array}{c}0.006 * * \\
(0.003)\end{array}$ & $\begin{array}{c}0.008 \\
(0.019)\end{array}$ & $\begin{array}{c}0.001 \\
(0.003)\end{array}$ & $\begin{array}{c}-0.045^{* * *} \\
(0.014)\end{array}$ & $\begin{array}{c}0.006^{* *} \\
(0.003)\end{array}$ & $\begin{array}{c}0.008 \\
(0.018)\end{array}$ & $\begin{array}{c}0.000 \\
(0.003)\end{array}$ \\
\hline Total time with spouse/partner & $\begin{array}{c}0.012 \\
(0.016)\end{array}$ & $\begin{array}{c}-0.003 \\
(0.003)\end{array}$ & $\begin{array}{l}-0.010 \\
(0.024)\end{array}$ & $\begin{array}{c}0.002 \\
(0.004)\end{array}$ & $\begin{array}{c}0.011 \\
(0.016)\end{array}$ & $\begin{array}{c}-0.004 \\
(0.003)\end{array}$ & $\begin{array}{l}-0.006 \\
(0.022)\end{array}$ & $\begin{array}{c}0.001 \\
(0.004)\end{array}$ \\
\hline Total time with hhld. Adult & $\begin{array}{l}-0.019 \\
(0.044)\end{array}$ & $\begin{array}{c}0.000 \\
(0.008)\end{array}$ & $\begin{array}{c}-0.009 \\
(0.050)\end{array}$ & $\begin{array}{l}-0.002 \\
(0.009)\end{array}$ & $\begin{array}{l}-0.016 \\
(0.043)\end{array}$ & $\begin{array}{c}0.002 \\
(0.008)\end{array}$ & $\begin{array}{l}-0.016 \\
(0.047)\end{array}$ & $\begin{array}{l}-0.001 \\
(0.008)\end{array}$ \\
\hline Total time with friend(s) & $\begin{array}{c}-0.025^{* * *} \\
(0.009)\end{array}$ & $\begin{array}{c}-0.001 \\
(0.002)\end{array}$ & $\begin{array}{l}-0.019 \\
(0.024)\end{array}$ & $\begin{array}{c}0.006 \\
(0.004)\end{array}$ & $\begin{array}{c}-0.025 * * * \\
(0.009)\end{array}$ & $\begin{array}{c}-0.001 \\
(0.002)\end{array}$ & $\begin{array}{c}-0.013 \\
(0.020)\end{array}$ & $\begin{array}{c}0.004 \\
(0.003)\end{array}$ \\
\hline Total time with co-workers & $\begin{array}{c}0.013 \\
(0.013)\end{array}$ & $\begin{array}{c}-0.004 \\
(0.002)\end{array}$ & $\begin{array}{c}0.035 \\
(0.026)\end{array}$ & $\begin{array}{l}-0.005 \\
(0.004)\end{array}$ & $\begin{array}{c}0.013 \\
(0.012)\end{array}$ & $\begin{array}{c}-0.004 \\
(0.002)\end{array}$ & $\begin{array}{c}0.030 \\
(0.022)\end{array}$ & $\begin{array}{c}-0.004 \\
(0.004)\end{array}$ \\
\hline Constant & $\begin{array}{c}2.540^{* * *} \\
(0.347)\end{array}$ & $\begin{array}{c}0.189 * * * \\
(0.067)\end{array}$ & $\begin{array}{l}1.518 * * \\
(0.641)\end{array}$ & $\begin{array}{c}0.555^{* * *} \\
(0.107)\end{array}$ & $\begin{array}{c}2.522 * * * \\
(0.342)\end{array}$ & $\begin{array}{c}0.176 * * * \\
(0.068)\end{array}$ & $\begin{array}{c}1.645^{* * *} \\
(0.560)\end{array}$ & $\begin{array}{c}0.527 * * * \\
(0.093)\end{array}$ \\
\hline $\begin{array}{l}\text { Sargan Test } \chi^{2}(1) \\
(p \text {-value })\end{array}$ & - & - & - & - & $\begin{array}{c}0.103 \\
(0.749)\end{array}$ & $\begin{array}{c}1.452 \\
(0.228)\end{array}$ & - & - \\
\hline $\begin{array}{l}\text { First-stage: } \text { dep var = Participation i } \\
\text { Deduction for charitable giving }\end{array}$ & \multicolumn{2}{|c|}{$\begin{array}{c}0.012 \\
(0.002)\end{array}$} & \multicolumn{2}{|c|}{$\begin{array}{c}0.011 \\
(0.003)\end{array}$} & \multicolumn{2}{|c|}{$\begin{array}{c}0.013 \\
(0.002)\end{array}$} & \multicolumn{2}{|c|}{$\begin{array}{c}0.012 \\
(0.003)\end{array}$} \\
\hline Nonprofit instituions/10,000 inhab. & \multicolumn{2}{|c|}{-} & & \multicolumn{2}{|c|}{$\begin{array}{c}-0.022 \\
(0.013)\end{array}$} & & \\
\hline $\begin{array}{l}\text { F-test of excluded instruments } \\
\text { (p-value) }\end{array}$ & \multicolumn{2}{|c|}{$(0.00)$} & - & - & \multicolumn{2}{|c|}{$\begin{array}{l}14.94 \\
(0.00)\end{array}$} & - & - \\
\hline $\begin{array}{l}\text { Observations } \\
\text { R-squared }\end{array}$ & $\begin{array}{c}25,601 \\
0.056\end{array}$ & $\begin{array}{c}25,601 \\
0.036\end{array}$ & $\begin{array}{c}25,143 \\
0.036\end{array}$ & $\begin{array}{c}25,143 \\
0.017\end{array}$ & $\begin{array}{c}25,601 \\
0.058\end{array}$ & $\begin{array}{c}25,601 \\
0.080\end{array}$ & $\begin{array}{c}25,143 \\
0.052\end{array}$ & $\begin{array}{c}25,143 \\
0.033\end{array}$ \\
\hline
\end{tabular}

Note: Sample consists of non-retired/non-students respondents between 21-65 years old from the ATUS 2010 Well-being Module. Robust standard errors in parentheses. Columns (1) and (2) show the IV 2SLS results for the net-affect and u-index respectively, when deduction for charitable gifts is used as instrument. Columns (3) and (4) show the G2SLS randon-effect results for the net-affect and u-index respectively, when deduction for charitable gifts is used as instrument. Columns (5) and (6) show the IV 2SLS results for the net-affect and u-index respectively, when deduction for charitable gifts and the number of nonprofit instituions per 10,000 inhabitants are used as instrument. Columns (7) and (8) show the G2SLS randon-effect results for the net-affect and u-index respectively, when deduction for charitable gifts and the number of nonprofit instituions per 10,000 inhabitants inhabitants are used as instrument. We also include day-of-week dummies in all of the regressions (ref.: Friday), variable dummies to control for residence in the Northeast, Midwest and South (ref.: West.), and the time of the day (e.g., time band) and its square * Significant at the $10 \%$ level ** Significant at the $5 \%$ level *** Significant at the $1 \%$ level. 
Table 7. Time use and daily happiness by activity and participation in voluntary activities

\begin{tabular}{|c|c|c|c|c|c|c|c|c|c|c|c|c|}
\hline & \multicolumn{4}{|c|}{ Time } & \multicolumn{4}{|c|}{ Net Affect } & \multicolumn{4}{|c|}{ u-index } \\
\hline & V & NV & Diff & $\begin{array}{c}\text { P-value } \\
\text { Diff }\end{array}$ & $\mathbf{V}$ & NV & Diff & $\begin{array}{c}\text { P-value } \\
\text { Diff }\end{array}$ & V & NV & Diff & P-value Diff \\
\hline Voluntary activities & 102.733 & - & - & - & 3.483 & - & - & - & 0.194 & - & - & \\
\hline Supervisory child care & 7.030 & 7.511 & -0.481 & $(0.68)$ & 4.984 & 4.503 & 0.481 & $(0.18)$ & 0.092 & 0.061 & 0.031 & $(0.60)$ \\
\hline Out-of-home leisure & 30.765 & 21.883 & 8.881 & $(0.00)$ & 4.537 & 4.126 & 0.411 & $(0.02)$ & 0.060 & 0.092 & -0.032 & $(0.35)$ \\
\hline Religious activities & 0.117 & 0.003 & 0.115 & $(0.00)$ & 4.043 & 3.828 & 0.214 & $(0.60)$ & 0.115 & 0.189 & -0.075 & $(0.16)$ \\
\hline Teaching child care & 7.490 & 5.700 & 1.790 & $(0.03)$ & 2.167 & 3.751 & -1.583 & $(0.00)$ & 0.297 & 0.151 & 0.146 & $(0.04)$ \\
\hline Sports/exercise & 10.423 & 15.032 & -4.609 & $(0.00)$ & 2.919 & 3.447 & -0.527 & $(0.17)$ & 0.295 & 0.150 & 0.144 & $(0.03)$ \\
\hline Basic Child care & 29.950 & 22.474 & 7.477 & $(0.00)$ & 3.342 & 3.409 & -0.067 & $(0.65)$ & 0.201 & 0.195 & 0.006 & $(0.82)$ \\
\hline Eating & 52.273 & 52.920 & -0.647 & $(0.67)$ & 3.374 & 3.343 & 0.031 & $(0.82)$ & 0.159 & 0.179 & -0.020 & $(0.36)$ \\
\hline At-home leisure & 60.175 & 62.059 & -1.884 & $(0.59)$ & 3.363 & 3.263 & 0.100 & $(0.60)$ & 0.174 & 0.209 & -0.034 & $(0.25)$ \\
\hline Reading/listening & 16.449 & 15.688 & 0.760 & $(0.62)$ & 2.694 & 3.177 & -0.483 & $(0.23)$ & 0.338 & 0.187 & 0.151 & $(0.04)$ \\
\hline Gardening/pet care & 14.563 & 18.753 & -4.189 & $(0.03)$ & 3.549 & 3.059 & 0.490 & $(0.14)$ & 0.151 & 0.229 & -0.078 & $(0.21)$ \\
\hline Leisure travel & 12.407 & 14.931 & -2.524 & $(0.09)$ & 3.332 & 2.984 & 0.348 & $(0.10)$ & 0.207 & 0.197 & 0.009 & $(0.80)$ \\
\hline Personal care & 15.966 & 13.988 & 1.978 & $(0.12)$ & 3.205 & 2.966 & 0.239 & $(0.30)$ & 0.222 & 0.192 & 0.030 & $(0.47)$ \\
\hline Cooking, meals & 39.129 & 35.118 & 4.011 & $(0.02)$ & 3.215 & 2.953 & 0.263 & $(0.10)$ & 0.191 & 0.224 & -0.033 & $(0.25)$ \\
\hline Adult care & 11.737 & 11.734 & 0.003 & $(1.00)$ & 2.635 & 2.975 & -0.340 & $(0.43)$ & 0.494 & 0.255 & 0.239 & $(0.00)$ \\
\hline Writing/paperwork & 18.009 & 18.470 & -0.461 & $(0.78)$ & 3.007 & 2.782 & 0.225 & $(0.38)$ & 0.157 & 0.282 & -0.125 & $(0.02)$ \\
\hline TV watching & 91.447 & 150.092 & -58.645 & $(0.00)$ & 2.995 & 2.668 & 0.326 & $(0.10)$ & 0.281 & 0.263 & 0.018 & $(0.61)$ \\
\hline Shopping & 31.433 & 27.931 & 3.502 & $(0.05)$ & 2.651 & 2.650 & 0.001 & $(1.00)$ & 0.284 & 0.287 & -0.003 & $(0.95)$ \\
\hline Commuting/work related & 14.261 & 23.306 & -9.045 & $(0.00)$ & 3.024 & 2.618 & 0.406 & $(0.08)$ & 0.188 & 0.272 & -0.084 & $(0.08)$ \\
\hline Other housework & 27.694 & 28.324 & -0.630 & $(0.70)$ & 2.807 & 2.604 & 0.203 & $(0.22)$ & 0.230 & 0.273 & -0.043 & $(0.15)$ \\
\hline Education & 1.298 & 2.183 & -0.885 & $(0.34)$ & 3.283 & 2.360 & 0.923 & $(0.58)$ & 0.000 & 0.279 & -0.279 & $(0.30)$ \\
\hline Housework & 49.625 & 42.439 & 7.187 & $(0.01)$ & 3.007 & 2.263 & 0.744 & $(0.00)$ & 0.183 & 0.305 & -0.122 & $(0.00)$ \\
\hline Main work & 166.082 & 275.370 & -109.288 & $(0.00)$ & 2.043 & 2.285 & -0.242 & $(0.25)$ & 0.281 & 0.331 & -0.050 & $(0.25)$ \\
\hline Home/car maintenance & 4.120 & 5.781 & -1.661 & $(0.15)$ & 2.370 & 2.061 & 0.309 & $(0.60)$ & 0.426 & 0.293 & 0.133 & $(0.27)$ \\
\hline Job search & 2.615 & 5.263 & -2.648 & $(0.05)$ & -0.150 & 1.620 & -1.770 & $(0.14)$ & 0.892 & 0.481 & 0.411 & $(0.11)$ \\
\hline Own medical care & 0.961 & 4.971 & -4.010 & $(0.01)$ & 0.203 & -0.073 & 0.276 & $(0.82)$ & 0.544 & 0.742 & -0.198 & $(0.26)$ \\
\hline Sleeping & 495.884 & 501.801 & -5.917 & $(0.17)$ & - & - & - & - & & - & 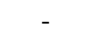 & 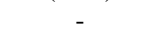 \\
\hline
\end{tabular}

Note: Sample consists of episodes from non-retired/non-students respondents between 21-65 years old from the ATUS 2010 Well-being Module. Means are compute using the original weights included in the survey. For time in the different activities, we consdier the information at the diary level, taking the total time devoted to the reference activity during the day. We show the difference in time use and happiness between volunteers and non-volunteers, and in parenthesis the p-value of the difference based on a t-test type test. 
Table 8. Decomposition of difference in daily happiness. Panel A: Counterfactual based on different Affective Well-Being

\begin{tabular}{lcc}
\hline Volunteering & 3.113 & 0.194 \\
Personality effect & 0.179 & -0.020 \\
Time-composition effect & 0.206 & -0.051 \\
Non-Volunteering & 2.728 & 0.265
\end{tabular}

Difference Volunteering/Non-Volunteering $\quad 0.385 \quad-0.071$

Panel B: Counterfactual based on different uses of time

$\begin{array}{lcc}\text { Volunteering } & 3.113 & 0.194 \\ \text { Personality effect } & 0.042 & -0.018 \\ \text { Time-composition effect } & 0.343 & -0.053 \\ \text { Non-Volunteering } & 2.728 & 0.265\end{array}$

$\begin{array}{lll}\text { Difference Volunteering/Non-Volunteering } & 0.385 & -0.071\end{array}$

Note: Sample consists of non-retired/non-students respondents between 21-65 years old from the ATUS 2010 Well-being Module. Standard deviations in parentheses. Activity weights are used and computed as the proportion of the activity out of the total waking time. 